\title{
昭苏山地草甸4种典型土地利用方式下的土壤呼吸 特征
}

王 祥 ${ }^{1}$ 朱亚琼 ${ }^{1}$ 郑 伟 ${ }^{1,2 *}$ 关正買 ${ }^{1}$ 盛建东 ${ }^{1}$

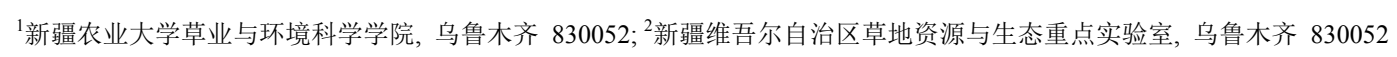

摘 要 为探讨不同土地利用方式对新疆昭苏天山北坡山地草甸土壤呼吸速率的影响, 于2015年和2016年的4月底至9月初, 用土壤呼吸测量仪对补播草地 $(R G) 、$ 豆禾混播草地 $(\mathrm{LG}) 、$ 围封草地 $(\mathrm{NG})$ 和农田 $(\mathrm{CR})$ 的土壤呼吸进行测定, 并分析了影响土壤 呼吸速率的土壤生物和水热因子。结果表明: 1)土壤呼吸速率在2015年NG和CR呈现双峰值, RG和LG呈现单峰曲线, 各处理均 在 8 月达到最大值。2016年各处理峰值出现的时间不同, RG 和LG在6月底达到最大值, NG和CR在7月底达到最大值; 监测期内 平均土壤呼吸速率由大到小依次为: $\mathrm{NG}>\mathrm{RG}>\mathrm{CR}>\mathrm{LG}$ 。2)各样地土壤呼吸速率与土壤温度呈指数正相关关系; 土壤含水量 与土壤呼吸的关系可能由于此地段常年湿润, 土壤含水量较高, 从而抑制土壤呼吸, 土壤呼吸与土壤体积含水量呈线性负相 关关系; 土壤呼吸的温度敏感指数 $\left(Q_{10}\right)$ 大小为 $\left.N G>C R>R G>L G \circ 3\right)$ 不同处理的土壤微生物以细菌为主, 放线菌次之, 真菌 居第三, 各样地总微生物生物量为: $\mathrm{NG}>\mathrm{RG}>\mathrm{CR}>\mathrm{LG}$, 与各样地平均土壤呼吸速率大小一致, 拟合分析显示 $\mathrm{RG}$ 土壤呼吸 与放线菌呈显著的线性相关关系, LG土壤呼吸与细菌和放线菌呈显著线性相关关系。不同处理微生物生物量碳平均含量为 $\mathrm{CR}>\mathrm{NG}>\mathrm{LG}>\mathrm{RG}$, 拟合分析显示 $\mathrm{RG}$ 与 $\mathrm{CR}$ 的土壤呼吸速率与微生物生物量碳呈显著线性相关关系, 其中 $\mathrm{CR}$ 的土壤呼吸速 率与微生物生物量碳极显著相关; 4)各样地酶活性与土壤呼吸的相关关系分析显示, 只有蛋白酶和蔗糖酶与土壤呼吸有相关 关系, 而蔗糖酶对土壤呼吸的影响更大。豆禾混播草地和补播草地相对于围封草地和农田, 土壤呼吸速率显著降低, 草地土 壤的固碳能力显著提高。

关键词 土地利用方式; 山地草甸; 土壤呼吸速率; 土壤温度; 土壤含水量; 土壤微生物; 土壤微生物生物量碳; 土壤酶活性 王祥, 朱亚琼, 郑伟, 关正噮, 盛建东 (2018). 昭苏山地草甸4种典型土地利用方式下的土壤呼吸特征. 植物生态学报, 42, 382-396. DOI: 10.17521/cjpe.2017.0050

\section{Soil respiration features of mountain meadows under four typical land use types in Zhaosu Basin}

WANG Xiang $^{1}$, ZHU Ya-Qiong ${ }^{1}$, ZHENG Wei ${ }^{1,2^{*}}$, GUAN Zheng-Xuan ${ }^{1}$, and SHENG Jian-Dong ${ }^{1}$

${ }^{1}$ College of Pratacultural and Environmental Science, Xinjiang Agricultural University, Ürümqi 830052, China; and ${ }^{2}$ Xinjiang Key Laboratory of Grassland Resources and Ecology, Ürümqi 830052, China

\section{Abstract}

Aims Our objective was to explore the effects of different land use types on soil respiration rates in the mountain meadows of Tianshan Mountain, Zhaosu Racecourse, Xinjiang, China from 2015 to 2016.

Methods Four impermanent plots with different land use types (legume-grass mixture, LG; reseeding grassland, RG; natural grassland, NG; cropland, CR), which were established in 2013, were selected. The soil respiration rates in the growing seasons of two consecutive years (from April to September in 2015 and 2016) were measured using LI-8100A Soil Respiration System. Soil temperatures at $5 \mathrm{~cm}$ depth and soil water content at $0-10 \mathrm{~cm}$ depth were measured simultaneously. We also investigated soil biological properties including soil microflora structures, soil microbial biomass carbon, and soil enzyme activity. The hydrothermal and soil biological impacts on soil respiration rates were analyzed using the relationship among soil hydrothermal factors, soil microflora factors, and soil enzyme activities.

Important findings We found that: 1) in 2015, the temporal variation of soil respiration showed double peaks in

收稿日期Received: 2017-03-02 接受日期Accepted: 2017-09-29

基金项目：中国科学院战略性先导科技专项(XDA05050405)、国家自然科学基金(31660692)和农业部“国家牧草产业技术体系”项目(CARS34)。 Supported by the Strategic Priority Research Program of Chinese Academy of Sciences (XDA05050405), the Natural Science Foundation of China (31660692) and the Modern Agroindustry Technology Research System (CARS34).

* 通信作者Corresponding author (zw065@126.com) 
NG and RC plots, but showed a single peak in RG and LG plots, and it reached the maximum in August in all plots. This temporal pattern was different in 2016. Soil respiration reached the maximum at the end of June in RG and LG, and at the end of July in NG and CR. 2) For the whole study period, the average soil respiration rate was in the order of: $\mathrm{NG}>\mathrm{RG}>\mathrm{CR}>\mathrm{LG}$. 3) Soil respiration rate was positively correlated with soil temperature, and negatively correlated with soil volumetric water content. The temperature sensitivity of soil respiration $\left(Q_{10}\right)$ was in the order of: $\mathrm{NG}>\mathrm{CR}>\mathrm{RG}>$ LG. 4) Bacteria were dominant among soil microbes in all type of plots, followed by actinomycetes and fungi were the least abundant. The total soil microbial biomass was in the order of: $\mathrm{NG}>\mathrm{RG}>\mathrm{CR}>\mathrm{LG}$, which was consistent with the average soil respiration rate. The fitting analysis showed that soil respiration was positively correlated with the abundance of actinomycetes in $\mathrm{RG}(p<0.05)$, and was positively correlated with the abundances of bacteria and actinomycetes in LG $(p<0.05)$. 5) The average microbial biomass carbon was in the order of: $\mathrm{CR}>\mathrm{NG}>\mathrm{LG}>\mathrm{RG}$. Fidelity analysis showed that soil respiration rate was significantly positively correlated with microbial biomass carbon in GR and CR $(p<0.05)$. 6) Among the examined enzymes, only protease and sucrase had a correlation with soil respiration, with sucrase having a greater effect. Changing the degraded mountain meadow to legume-grass mixture and reseeding grassland could decrease soil respiration rates, potentially benefiting carbon sequestration.

Key words land use type; mountain meadow; soil respiration rate; soil temperature; soil water content; soil microflora; soil microbial carbon; soil enzyme activity

Wang X, Zhu YQ, Zheng W, Guan ZX, Sheng JD (2018). Soil respiration features of mountain meadows under four typical land use types in Zhaosu Basin. Chinese Journal of Plant Ecology, 42, 382-396. DOI: 10.17521/cjpe.2017.0050

土地利用方式的变化及其导致的植被变化是影 响陆地生态系统碳循环的一个关键因素(Willcock et al., 2016): 其通过改变土壤微环境、土壤物理化学 过程和土壤微生物活动, 进而影响土壤 $\mathrm{CO}_{2}$ 的产生 与排放(Flechard et al., 2007; 刘慧峰等, 2014)。当前, 由人类活动引起的草地利用/土地利用方式的变化 导致的陆地生态系统变化对全球碳循环有重要的影 响。如Sampson等(1993)就认为, 草地开虎后, 虽然 植被生产力有所提高, 但由于土壤呼吸增强, 土壤 有机碳储量下降; 刘季骢等(2014)也认为, 无论草 地开艮还是农田退耕还草, 均会增加土壤呼吸速率, 进而增加碳排放。因此, 准确地估计草地利用/土地 利用方式变化对陆地生态系统碳循环和碳平衡的影 响是当前全球气候变化和碳循环的研究重点(Sampson et al., 1993)。

目前, 对天然草地的利用方式中, 放牧、割草和 围封是最主要的方式(宁发等, 2008)。郭明英等(2012) 对呼伦贝尔羊草草甸草原3种不同利用方式(围封、 放牧和刈割)下的土壤呼吸和土壤微生物特性进行 了研究, 结果表明不同利用方式下土壤呼吸速率表 现为围封比放牧和刈割高, 其微生物生物量碳和过 氧化氢酶活性也较高。王忆慧等(2015)则发现, 在干 旱年份土壤呼吸最高的是放牧样地, 而湿润年份是 刏割样地, 水分是影响温带草原碳循环的重要限制 因素。不同草地土地利用方式一方面通过改变根系
呼吸(Hanson et al., 2000), 扰动土壤(Lal et al., 1998), 导致土壤水分、温度(王小国等, 2007)和土壤有机碳 (Lal，2004)发生显著变化，进而抑制或促进微生物 活性，降低或加快土壤呼吸; 另一方面也改变了土 壤理化性质, 从而对土壤呼吸产生很大影响 (Sparling et al., 1992)。草地开垦是引起草原土壤碳 减少的最强烈的人为因素。草地开垦过程会破坏土 壤中致密的根系, 使土壤深层的有机质暴露在空气 中, 从而加速了其分解过程, 导致土壤呼吸作用增 强(Anderson \& Coleman, 1985)。张平良等(2007)研 究发现在高寒地区种植的人工草地固碳效率是撂荒 地的1-2倍, 从而提高了碳储量, 降低了土壤呼吸。 但也有研究表明人工草地的建植也可能降低土壤有 机碳含量, 或对土壤有机碳没有影响, 如加拿大开 唇天然草原种植冰草(Agropyron cristatum) 13年后, 土壤碳储量和对照相比无显著变化(Wang, 2010)。

退化的生态系统恢复成草地往往是理想的生态 选择, 能够增加水分利用效率, 增加碳储量, 减少 温室气体排放(Zhang et al., 2015)。进一步讲, 利用 豆禾牧草混播进行的草地补播/重建、间混作改良农 田不仅有利于植被的恢复, 而且能有效地提高土地 的固碳能力(张英俊等, 2013; Raiesi \& Beheshti, 2014)。然而, 现有关于对退化草地进行人工补播改 良或重建为人工草地的研究中, 多集中在牧草产 量、品质和土壤养分利用改善方面，对土地利用方 
式改变后土壤碳循环(包括土壤呼吸)的研究较少。 本研究选取新疆伊犁昭苏马场退化山地草甸为研究 对象, 将地势开阔、植被相对均一、土壤类型一致 的退化山地草甸翻耕建成的豆禾混播草地, 补播改 良成的豆禾补播草地, 围封草地, 以及开垦成种植 春小麦(Triticum aestivum)的农田作为此次试验的研 究对象, 试从上述当地 4 种典型土地利用方式入手, 研究土地利用方式变化对新疆天山北坡西段山地草 甸土壤呼吸特征的影响, 并探讨影响土壤呼吸的生 物和非生物因素, 以期为天山北坡山地草甸不同草 地土地利用方式下的草地碳汇管理机制提供依据, 并为深入理解我国草地生态系统碳循环过程和草地 生态系统碳平衡估算提供依据。

\section{1 材料和方法}

\section{1 研究区概况}

试验地点位于新疆维吾尔自治区伊犁哈萨克自 治州昭苏县的昭苏马场 $\left(81.05^{\circ}-81.08^{\circ} \mathrm{E}\right.$, $40.92^{\circ}-43.25^{\circ} \mathrm{N}$ ), 属于大陆性温带山区半干旱半湿 润冷凉气候。2014-2015年平均气温为 $4.1{ }^{\circ} \mathrm{C}$, ? $10{ }^{\circ} \mathrm{C}$ 年积温为 $1416.8{ }^{\circ} \mathrm{C}$, 无霜期 85-100天, 2014-2015年平均年降水量为490.1 $\mathrm{mm}$, 降水集中 于 5-10月, 约占全年总降水量的 $74 \%$, 平均年蒸发 量 $1261.6 \mathrm{~mm}$, 约是降水量的 2.5 倍, 积雪期 158 天, 积雪厚度20-60 cm。试验小区位于天山北坡西段山 地草甸, 未退化山地草甸植被主要成分有鸭茅 (Dactylis glomerata)、无芒雀麦(Bromus inermis)、新 疆鹅观草(Roegneria sinkiangensis)、猫尾草(Phleum pratense)、草原糙苏(Phlomis pratensis)、草地老鹳 草 (Geranium pratense)、大叶稁吾 (Ligularia macrophylla)等。盖度 $85 \%-100 \%$, 草层高 $45-85 \mathrm{~cm}$, 鲜草产量4 300-9 050 kg $\cdot \mathrm{hm}^{-2}$ 。土壤为黑钙土, 0-5 $\mathrm{cm}$ 土壤有机碳含量为 $7.91 \%-8.64 \%$, 全氮、全磷、 全钾含量分别为 $9.53 、 2.16$ 和 $12.20 \mathrm{~g} \cdot \mathrm{kg}^{-1}$, 碱解氮、 有效磷、有效钾含量分别为459.20、144.43和 473.58 $\mathrm{mg} \cdot \mathrm{kg}^{-1}$ (郑伟等, 2015)。退化山地草甸植被特征为: 植被主要成分有野苜宿(Medicago falcata)、草地早 熟禾 (Poa pratensis)、拂子茅 (Calamagrostis epigeios)、短柄臺草(Carex pediformis)、直立委陵菜 (Potentilla recta)、野草莓(Fragaria vesca)、千叶著 (Achillea millefolium) 等, 盖度 $75 \%$, 草层高度 $25 \mathrm{~cm}$, 鲜草产量 $1300 \mathrm{~kg} \cdot \mathrm{hm}^{-2}$ 。0-5 cm 土壤有机碳下降为
$6.03 \%$, 土壤其他理化性质变化较小(王雪娇, 2013)。

\section{2 样地选择}

选择围封的围封草地 $(\mathrm{NG})$ 、补播草地 $(\mathrm{RG})$ 、翻 耕重建的豆禾混播草地(LG)和农田(CR) 为研究对 象。其中, 天然草地为退化山地草甸进行围封(围封 开始年为2011年, 2012年后开始割草利用); 补播草 地为退化山地草甸上补播鸭茅、无芒雀麦、猫尾草、 紫苜宿 (Medicago sativa)、驴食草(又名红豆草) (Onobrychis viciifolia) 和红车轴草(Trifolium pratense), 豆禾比为5:5 (补播年份为2011年, 2012年后 开始割草利用); 豆禾混播草地为退化山地草甸翻 耕重建成鸭茅、无芒雀麦、猫尾草、紫苜宿、驴食 草和红车轴草的豆禾混播草地, 豆禾比为5:5 (建植 年份为2011年, 2012年后开始割草利用); 2014年将 退化山地草甸开垦成农田, 2015年和2016年均种植 春小麦, 春小麦每年4月初至4月中旬播种, 9月初至 9月中旬收割。

\section{3 研究方法}

\subsection{1 土壤呼吸日动态及水热的测定}

土壤呼吸的测定时间在2015年4月底至9月初和 2016年4月底至9月初, 用LI-8100A (LI-COR, Lincoln NE, USA)对各样地进行测定, 在2015-5-29、 2015-6-20、2015-7-6、2015-7-27、2015-8-17、2015-9-1; $2016-4-19$ 、2016-5-14 、2016-6-1 、2016-6-29 、 2016-7-27、2016-8-13、2016-9-5测定各样地土壤呼 吸日变化, 并根据天气预报尽量选择晴朗天气对各 样地进行监测。测定前 $24 \mathrm{~h}$ 将直径 $20 \mathrm{~cm}$ 、高 $20 \mathrm{~cm}$ 的 $\mathrm{PVC}$ 基座嵌入土壤中, 每样地设置 3 个相距 $10 \mathrm{~m}$, 露出地面 $5 \mathrm{~cm}$ 的PVC基座; 同时, 将基座内的绿色 植物齐地面剪掉，但尽量不破坏土壤，以减少土壤 扰动及根系损伤对测量结果的影响。经 $24 \mathrm{~h}$ 的平衡 后，在一天内 9 个时间点(北京时间6:00、8:00、10:00、 12:00、14:00、16:00、18:00、20:00、22:00)测定PVC 基座内的土壤呼吸速率。

同时, 用与预先埋下的针式地温计同步测定各 样地 $5 \mathrm{~cm}$ 地温。土壤含水量用烘干铝盒法测定, 取 样方法为在测定土壤呼吸的同时, 取相应样地 3 处 PVC基座附近0-10 cm土壤并混匀后装入铝盒带回 实验室。

\subsection{2 土壤微生物数量的测定}

土壤微生物数量测定采用平板涂抹接种法, 以 牛肉膏蛋白胨培养基培养细菌高氏 1 号培养基加重 
铬酸钾 $\left(3.30 \mathrm{~mL} \cdot \mathrm{L}^{-1}\right)$ 培养放线菌; 马丁氏培养基加 链霉素 $\left(3.30 \mathrm{~mL} \cdot \mathrm{L}^{-1}\right.$ )培养真菌。培养3-6天观察(许光 辉, 1986)。

\subsection{3 土壤微生物生物量碳的测定}

土壤采样于每次日变化测量结束后进行, 在各 地段随机选取 3 个土壤采样点, 取样深度为 $0-5 \mathrm{~cm}$, 从中取约 $100 \mathrm{~g}$ 土壤进行预培养, 其中约 $30 \mathrm{~g}$ 做熏蒸 处理, $30 \mathrm{~g}$ 做未熏蒸处理, $30 \mathrm{~g}$ 测含水量。微生物生物 量碳采用TOC分析仪(Elementar vario, Langenselbold, Germany)测定, 熏蒸试剂为氯仿。

\subsection{4 土壤酶活性的测定}

嫝酶活性的测定采用奈氏比色法, 以 $1 \mathrm{~g}$ 干土 $24 \mathrm{~h}$ 生成的 $\mathrm{NH}_{3}-\mathrm{N}$ 量为脲酶 1 个活性单位; 过氧化氢 酶活性的测定采用 $\mathrm{KMnO}_{4}$ 滴定法, 酶活性以 $1 \mathrm{~g}$ 干 土 $1 \mathrm{~h}$ 内消耗的 $0.1 \mathrm{~mol} \cdot \mathrm{L}^{-1} \mathrm{KMnO}_{4}$ 体积数 (以 $\mathrm{mL}$ 计) 表示; 转化酶活性的测定采用 3,5 -二硝基水杨酸比 色法, 酶活性以 $24 \mathrm{~h}$ 后 $1 \mathrm{~g}$ 土壤葡萄糖的 $\mathrm{mg}$ 数表示; 蛋白酶活性的测定采用铜盐比色法, 以 $1 \mathrm{~g}$ 土壤在 $24 \mathrm{~h}$ 内酶解蛋白质释放的质量代表蛋白酶的活性 (关松荫, 1986)。

\subsection{5 数据分析}

采用指数模型分析土壤呼吸和土壤温度月变化 的关系, 采用一元回归模型分析土壤呼吸和土壤含 水量月变化关系, 方程如下:

$$
\begin{aligned}
& R_{\mathrm{s}}=a \mathrm{e}^{b T_{\mathrm{s}}} \\
& Q_{10}=\mathrm{e}^{10 b} \\
& R_{\mathrm{s}}=c \times W_{10}+d
\end{aligned}
$$

式中, $R_{\mathrm{s}}$ 为土壤呼吸速率 $\left(\mathrm{mg} \cdot \mathrm{m}^{-2} \cdot \mathrm{h}^{-1}\right), a 、 b 、 c 、 d$ 为 拟合参数, $T_{\mathrm{s}}$ 为 $5 \mathrm{~cm}$ 深度的土壤温度 $\left({ }^{\circ} \mathrm{C}\right), Q_{10}$ 为土壤 呼吸的温度敏感性系数, 指土壤温度每增加 $10{ }^{\circ} \mathrm{C}$ 土壤呼吸速率所增加的倍数, $W_{10}$ 为 $10 \mathrm{~cm}$ 深度的土 壤体积含水量。

复合模型能较好地模拟土壤呼吸对温度和土壤 含水量的响应, 土壤温度和土壤含水量对土壤呼吸 速率的共同影响用多元非线性回归分析模型计算, 方程如下:

$$
R_{\mathrm{s}}=a \mathrm{e}^{10 T_{\mathrm{s}}}+c \times W_{10}^{2}+d \times W_{10}+f
$$

式中 $a, b 、 c 、 d 、 f$ 为拟合参数。

利用Microsoft Excel 2010进行数据整理, 使用 SPSS 20.0进行数据分析, 采用单因素方差分析方法 分析比较4种处理样地不同时期的土壤呼吸速率。利 用Origin Pro 8和Microsoft Excel 2010作图。

\section{2 结果和分析}

\section{1 各样地不同时期土壤呼吸的变化特征}

RG、LG、NG和CR土壤呼吸速率均表现出明显 的季节变化, 且有着较为相似的变化规律, 即在生 长季初期的4-5月最低, 在6-8月达到最高, 之后逐 渐降低。但各处理间的季节变化特征又有差异。2015 年各处理土壤呼吸速率季节变化表现为 $\mathrm{NG}$ 和 $\mathrm{CR}$ 均 为双峰曲线, 在6月出现一个峰值, 然后下降, 这个 下降的过程可能由于这个时期温度下降, 随之土壤 呼吸速率下降, $\mathrm{NG}$ 与 $\mathrm{CR}$ 的土壤呼吸对温度的响应 的更加迅速, 因此变化更为明显。 $\mathrm{NG}$ 与 $\mathrm{CR}$ 处理在 7 月又上升并达最大值, $N G$ 出现当年监测土壤呼吸速 率的最大值 $16.41 \mu \mathrm{mol} \cdot \mathrm{m}^{-2} \cdot \mathrm{s}^{-1}$, 随后下降; $\mathrm{RG}$ 与 $\mathrm{LG}$ 土壤呼吸季节变化呈现单峰曲线, 最大值分别为 13.63 和 $11.37 \mu \mathrm{mol} \cdot \mathrm{m}^{-2} \cdot \mathrm{s}^{-1}$ 。2016年各处理土壤呼吸 速率季节变化均呈现单峰曲线, 但各处理出现最大 值的时间不同, RG 和 LG土壤呼吸速率在6月底达到 最大值, 分别为 16.22 和 $17.97 \mu \mathrm{mol} \cdot \mathrm{m}^{-2} \cdot \mathrm{s}^{-1}$, 而 $\mathrm{NG}$ 与 $\mathrm{CR}$ 在 7 月底达到最大值, 分别为 19.68 和 17.84 $\mu \mathrm{mol} \cdot \mathrm{m}^{-2} \cdot \mathrm{s}^{-1} ; 2015$ 年平均土壤呼吸速率由大到小依 次为 $\mathrm{NG}\left(10.44 \mu \mathrm{mol} \cdot \mathrm{m}^{-2} \cdot \mathrm{s}^{-1}\right) 、 \mathrm{CR}\left(9.61 \mu \mathrm{mol} \cdot \mathrm{m}^{-2}\right.$. $\left.\mathrm{s}^{-1}\right) 、 \mathrm{RG}\left(8.65 \mu \mathrm{mol} \cdot \mathrm{m}^{-2} \cdot \mathrm{s}^{-1}\right) 、 \mathrm{LG}\left(8.49 \mu \mathrm{mol} \cdot \mathrm{m}^{-2} \cdot \mathrm{s}^{-1}\right)$ 。 2016 年平均土壤呼吸速率由大到小依次为 $\mathrm{NG}$ $\left(11.06 \mu \mathrm{mol} \cdot \mathrm{m}^{-2} \cdot \mathrm{s}^{-1}\right) 、 \mathrm{RG}\left(10.05 \mu \mathrm{mol} \cdot \mathrm{m}^{-2} \cdot \mathrm{s}^{-1}\right) 、 \mathrm{LG}$ $\left(9.79 \mu \mathrm{mol} \cdot \mathrm{m}^{-2} \cdot \mathrm{s}^{-1}\right) 、 \mathrm{CR}\left(9.70 \mu \mathrm{mol} \cdot \mathrm{m}^{-2} \cdot \mathrm{s}^{-1}\right) ; 2$ 年监测 的土壤呼吸速率平均值由大到小依次为: NG (10.83 $\left.\mu \mathrm{mol} \cdot \mathrm{m}^{-2} \cdot \mathrm{s}^{-1}\right) 、 \mathrm{RG}\left(9.53 \mu \mathrm{mol} \cdot \mathrm{m}^{-2} \cdot \mathrm{s}^{-1}\right) 、 \mathrm{CR}(9.46$ $\left.\mu \mathrm{mol} \cdot \mathrm{m}^{-2} \cdot \mathrm{s}^{-1}\right) 、$ LG $\left(9.19 \mu \mathrm{mol} \cdot \mathrm{m}^{-2} \cdot \mathrm{s}^{-1}\right)$ 。

对不同时期 4 种样地的土壤呼吸速率变化进行 方差分析显示, 在 2015 年 4 月 $\mathrm{CR}$ 与 $\mathrm{NG}$ 存在显著差 异 $(p<0.05)$, 与其他处理差异不显著 $(p>0.05) ; 6$ 月 $R G$ 与 $N G 、 C R$ 均存在显著差异 $(p<0.05)$, 而 $\mathrm{CR}$ 与其 他处理也存在显著差异 $(p<0.05)$; 在7月初和7月底 均表现为, $\mathrm{CR}$ 与其他 3 个处理存在显著差异 $(p<$ $0.05)$, 而其他 3 个处理间差异不显著 $(p>0.05)$; 在 8 月, $\mathrm{NG}$ 与 $\mathrm{RG} 、 \mathrm{LG}$ 存在显著差异 $(p<0.05)$, 与 $\mathrm{CR}$ 差 异不显著 $(p>0.05), \mathrm{RG}$ 与 $\mathrm{LG}$ 差异不显著 $(p>0.05)$; 9 月各处理均无显著差异 $(p>0.05)$ 。在2016年4月, $\mathrm{CR}$ 与其他各处理存在显著差异 $(\mathrm{p}<0.05)$, 而其他各 处理无显著差异 $(p>0.05)$; 而5月、6月初、6月底各 处理均无显著差异 $(p>0.05)$; 在7月底 NG与 $R G 、 L G$ 
存在显著差异 $(p<0.05)$ 、与 $\mathrm{CR}$ 差异不显著 $(p>0.05)$; 在 8 月, $\mathrm{RG}$ 与 $\mathrm{NG}$ 存在显著差异 $(p<0.05)$, 与其他处 理差异不显著 $(p>0.05), \mathrm{NG}$ 其他处理差异也不显著 $(p>0.05)$; 在9月初各处理差异均不显著(图1)。

\section{2 土壤温度和水分对土壤呼吸速率的影响}

不同利用方式下各样地土壤温度(图2)呈单峰 曲线, 在7-8月达到最大值, 利用模型(1)对各样地 $0-5 \mathrm{~cm}$ 处土壤温度 $\left(T_{\mathrm{s}}\right)$ 与土壤呼吸速率做相关性分 析(图3), RG、LG、NG样地土壤呼吸速率均和土壤 温度相关性达显著水平 $(p<0.05), \mathrm{CR}$ 不显著 $(p>$ 0.05 ); 利用模型(2)计算温度敏感指数 $Q_{10}$, 各样地 变化为 $N G>C R>R G>L G$ (图3)。各样地土壤含水
量与相应土壤呼吸速率相关关系利用模型(3)进行 模拟，结果表明RG、LG、NG和CR土壤含水量与土 壤呼吸速率均呈负相关关系(图4); 除 $\mathrm{CR}$ 的土壤含 水量与土壤呼吸速率相关性不显著外, 其余各样地 土壤呼吸速率均与土壤含水量显著相关, 且 $\mathrm{NG}$ 达到极显著。决定系数 $\left(R^{2}\right)$ 的大小为 $\mathrm{NG}>\mathrm{LG}>$ $\mathrm{RG}>\mathrm{CR}$ 。

复合模型能较好地模拟土壤呼吸对土壤温度和 土壤含水量变化的协同响应，因此采用复合模型(4) 计算土壤温度和水分对土壤呼吸的协同影响(表1), 结果表明, $R^{2}$ 较单因子模型均有不同程度的提高, 拟合效果更好, 土壤温度和水分共同解释土壤呼吸
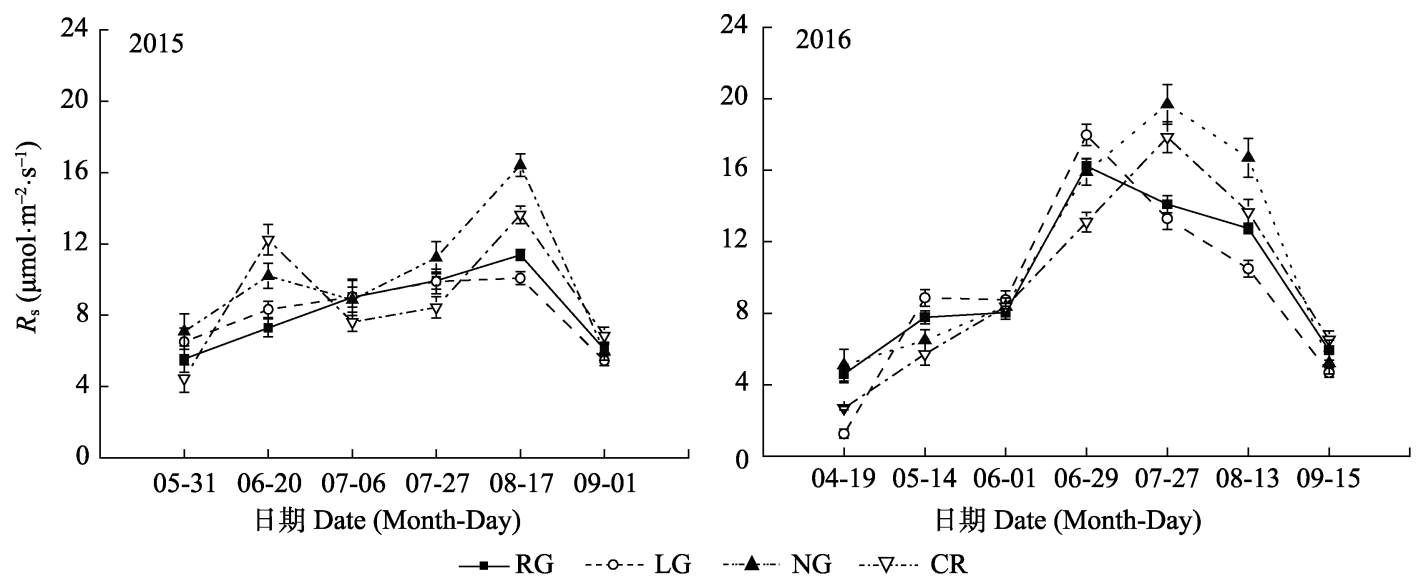

图1 不同土地利用方式下土壤呼吸速率 $\left(R_{\mathrm{s}}\right)$ 季节变化(平均值土标准偏差)。CR, 农田; LG, 豆禾混播草地; $\mathrm{NG}$, 围封草地; RG, 补播草地。

Fig. 1 Seasonal variation of soil respiration rate $\left(R_{\mathrm{s}}\right)$ in plots with different land use types (mean $\left.\pm S D\right)$. CR, cropland; LG, legume-grass mixture; NG, natural grassland; RG, reseeding grassland.

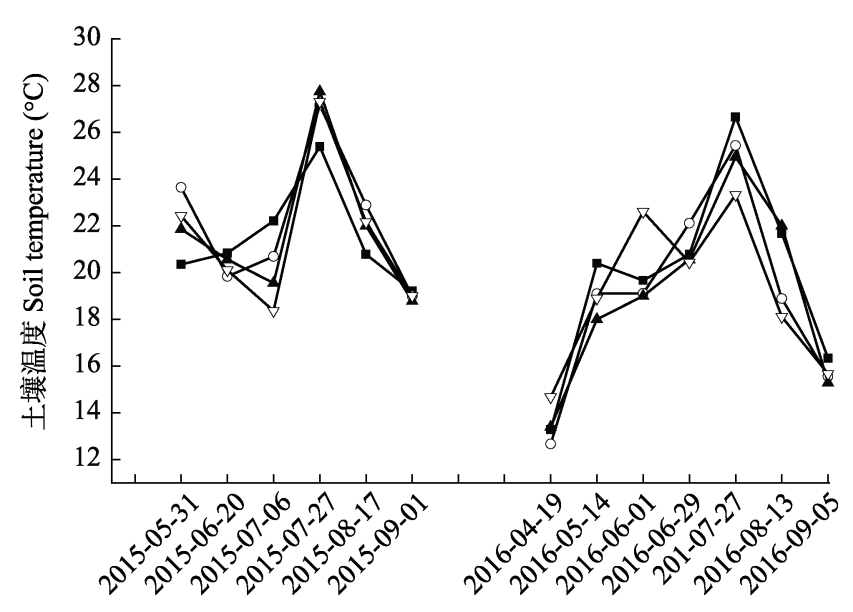

日期 Date

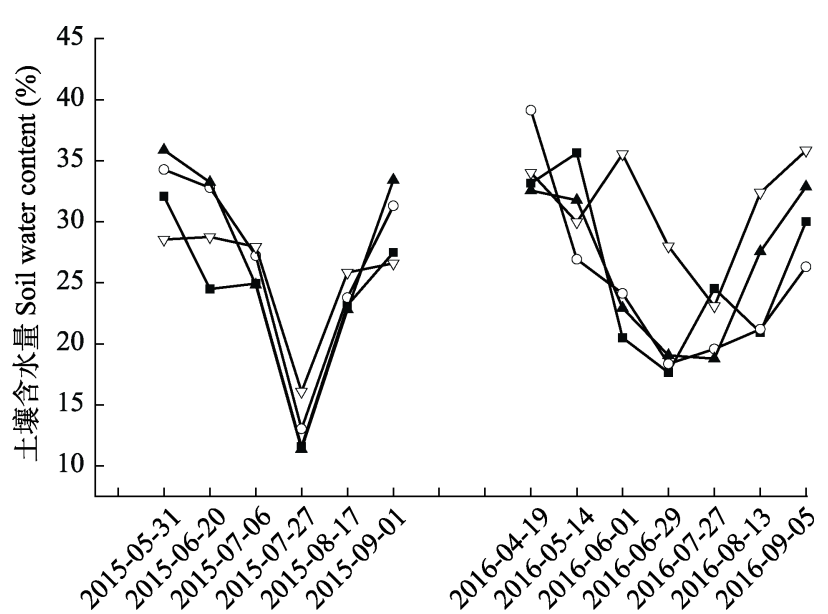

日期 Date

图2 不同土地利用方式下各样地土壤温度和土壤含水量。CR，农田; LG, 豆禾混播草地; NG, 围封草地; RG, 补播草地。

Fig. 2 Soil temperature and soil water content in plots with different land use types. CR, cropland; LG, legume-grass mixture; NG, natural grassland; $\mathrm{RG}$, reseeding grassland. 

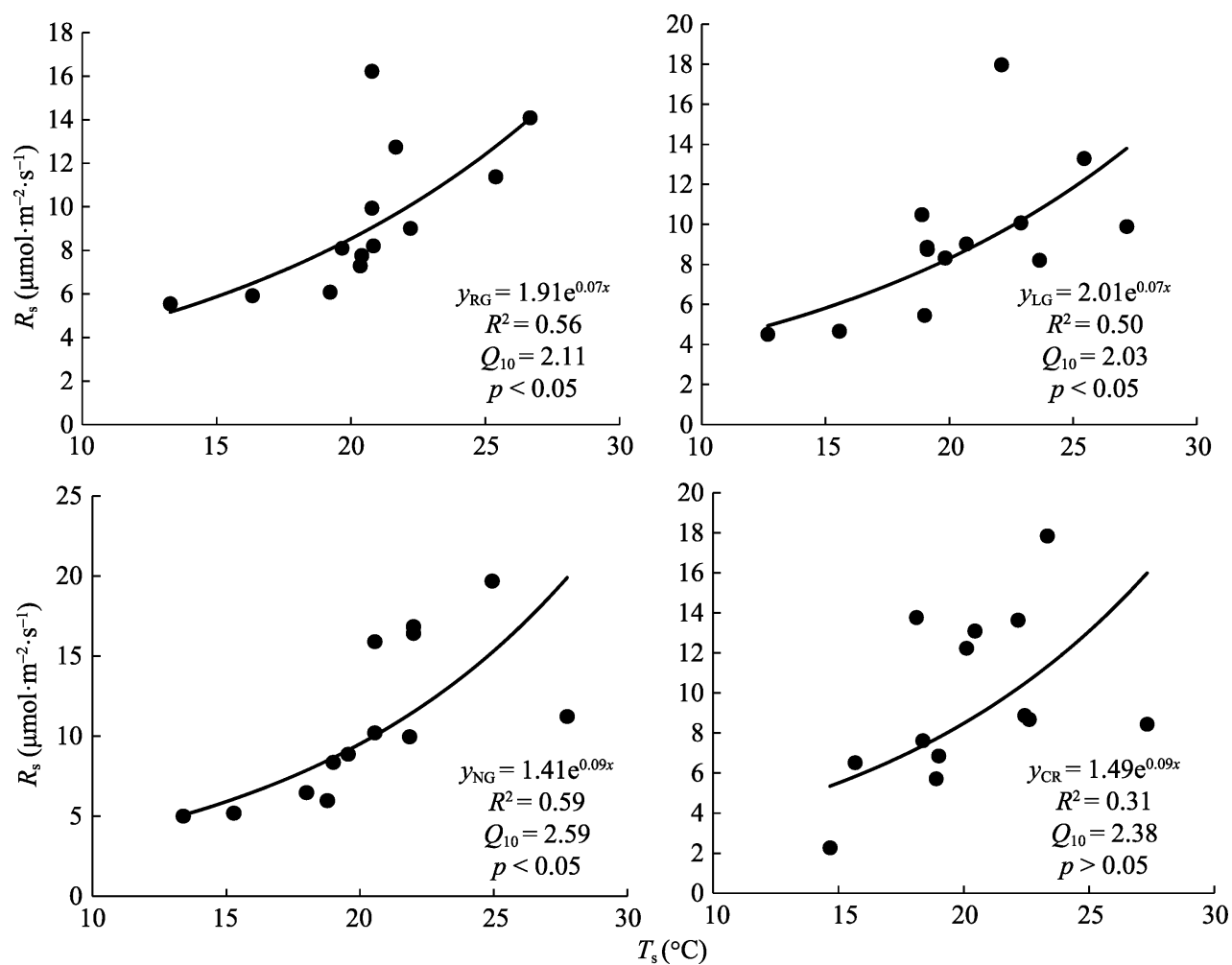

图3 不同土地利用方式下土壤呼吸速率 $\left(R_{\mathrm{S}}\right)$ 与 $5 \mathrm{~cm}$ 土壤温度的指数拟合关系。 $\mathrm{CR}$, 农田; $\mathrm{LG}$, 豆禾混播草地; $\mathrm{NG}$, 围封草地; $\mathrm{RG}$, 补播草地。

Fig. 3 The relationship between soil respiration rate $\left(R_{\mathrm{s}}\right)$ and soil temperature at $5 \mathrm{~cm}$ depth in plots with different land use types. CR, cropland; LG, legume-grass mixture; NG, natural grassland; RG, reseeding grassland.
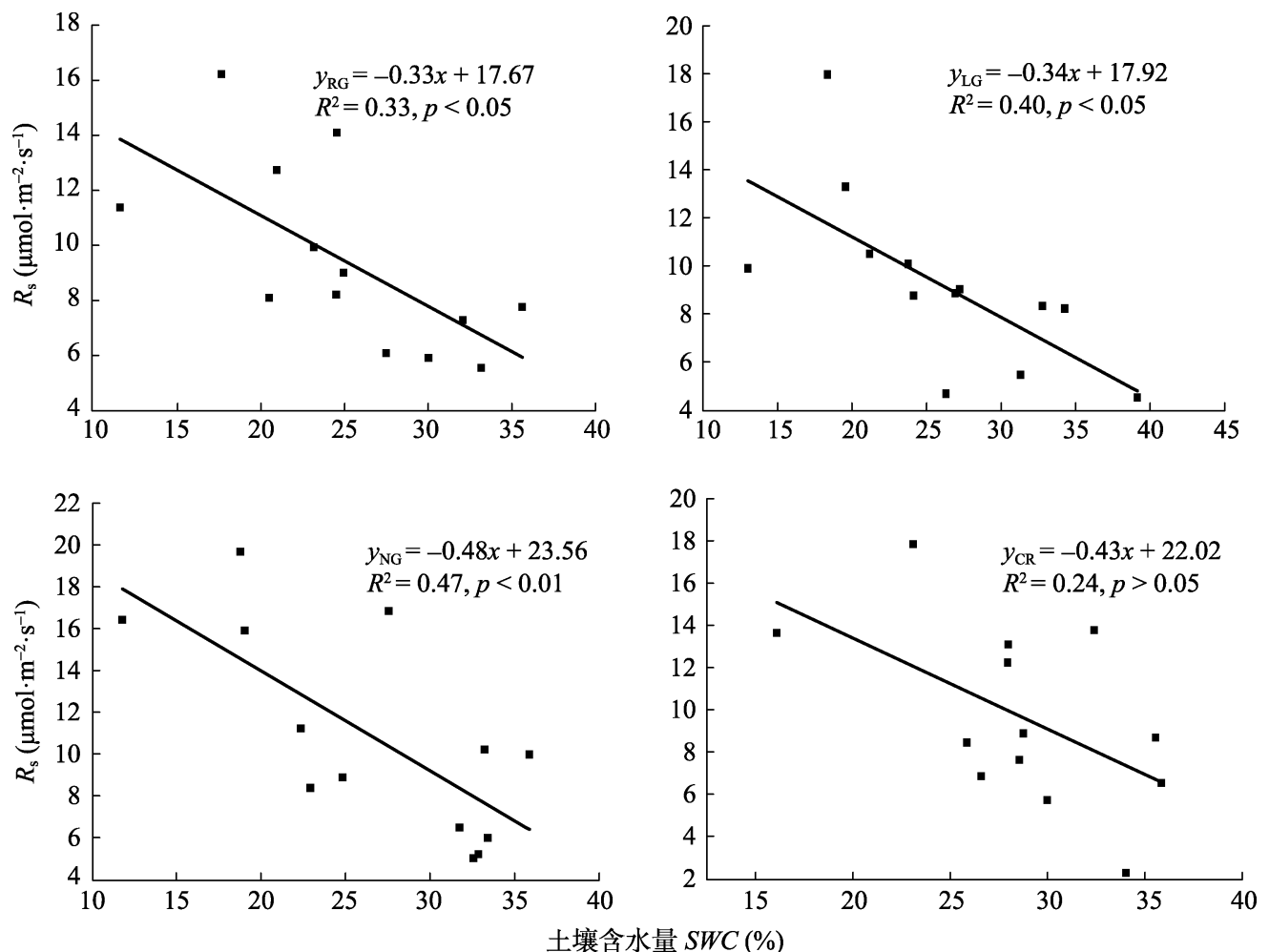

图4 不同土地利用方式下土壤呼吸速率 $\left(R_{\mathrm{s}}\right)$ 与 $10 \mathrm{~cm}$ 土壤含水量的线性拟合关系。 $\mathrm{CR}$, 农田; $\mathrm{LG}$, 豆禾混播草地; $\mathrm{NG}$, 围封草 地; RG，补播草地。

Fig. 4 The relationship between soil respiration rate $\left(R_{\mathrm{s}}\right)$ and soil water content $(S W C)$ at $10 \mathrm{~cm}$ depth in plots with different land use types. CR, cropland; LG, legume-grass mixture; NG, natural grassland; RG, reseeding grassland. 
速率变异度的 $64 \%-89 \%$ 。

\section{3 土壤微生物特征对土壤呼吸的影响}

不同土地利用方式对土壤微生物数量的影响如

表2所示, 从土壤微生物类群组成来看, 不同处理土
壤微生物数量以细菌为主, 放线菌次之, 真菌数量 最少, 细菌数量在土壤微生物组成中占绝对优势。 各类群微生物数量占微生物总数比例由大到小依次 为细菌>放线菌>真菌。

表1 土壤呼吸 $\left(R_{\mathrm{S}}\right)$ 与土壤温度 $\left(T_{\mathrm{s}}\right)$ 和土壤含水量 $\left(W_{10}\right)$ 的回归方程

Table 1 Regression equations of soil respiration rate $\left(R_{\mathrm{s}}\right)$ with soil temperature $\left(T_{\mathrm{s}}\right)$ and soil water content $\left(W_{10}\right)$

\begin{tabular}{|c|c|c|c|c|c|c|}
\hline \multirow{2}{*}{$\begin{array}{l}\text { 样地 } \\
\text { Plot }\end{array}$} & \multicolumn{3}{|l|}{2015} & \multicolumn{3}{|l|}{2016} \\
\hline & 拟合方程 Fitted equation & $R^{2}$ & $p$ & 拟合方程 Fitted equation & $R^{2}$ & $p$ \\
\hline RG & $R_{\mathrm{s}}=0.63 \mathrm{e}^{0.10 T \mathrm{~s}}+0.47 W_{10}^{2}-0.11 W_{10}-1.99$ & 0.81 & $<0.001$ & $R_{\mathrm{s}}=\mathrm{e}^{-0.99 T \mathrm{~s}}-0.60 W_{10}^{2}+0.63 W_{10}-0.73$ & 0.68 & $<0.01$ \\
\hline LG & $R_{\mathrm{s}}=0.92 \mathrm{e}^{0.09 T \mathrm{~s}}+1.22 W_{10}^{2}-0.02 W_{10}-12.45$ & 0.67 & $<0.01$ & $R_{\mathrm{s}}=\mathrm{e}^{-0.99 T \mathrm{~s}}+0.45_{10}^{2}-0.24 W_{10}-0.97$ & 0.89 & $<0.01$ \\
\hline NG & $R_{\mathrm{s}}=\mathrm{e}^{-0.95 T \mathrm{~s}}-0.49 W_{10}^{2}+0.49 W_{10}+0.47$ & 0.78 & $<0.001$ & $R_{\mathrm{s}}=0.46 \mathrm{e}^{0.14 T \mathrm{~s}}-0.02 W_{10}^{2}+0.64 W_{10}-1.73$ & 0.88 & $<0.01$ \\
\hline $\mathrm{CR}$ & $R_{\mathrm{s}}=\mathrm{e}^{-0.99 T \mathrm{~s}}-0.79 W_{10}^{2}+0.85 W_{10}-0.29$ & 0.68 & $<0.01$ & $R_{\mathrm{s}}=\mathrm{e}^{-T \mathrm{~s}}+0.86 W_{10}^{2}-0.86 W_{10}+0.42$ & 0.64 & $<0.01$ \\
\hline
\end{tabular}

$\mathrm{CR}$, 农田; LG, 豆禾混播草地; $\mathrm{NG}$, 围封草地; RG, 补播草地。

$\mathrm{CR}$, cropland; LG, legume-grass mixture; NG, natural grassland; RG, reseeding grassland.

表2 不同土地利用方式下土壤微生物区系构成 $\left(\mathrm{cfu} \cdot \mathrm{g}^{-1} \mathrm{dry}\right.$ soil)(平均值土标准偏差, $n=3$ )

Table 2 Soil microflora in four plots with different land use types $\left(\mathrm{cfu} \cdot \mathrm{g}^{-1}\right.$ dry soil) $($ mean $\pm S D, n=3)$

\begin{tabular}{|c|c|c|c|c|c|c|c|c|}
\hline \multirow{2}{*}{$\begin{array}{l}\text { 时期 } \\
\text { Time }\end{array}$} & \multirow{2}{*}{$\begin{array}{l}\text { 样地 } \\
\text { Plot }\end{array}$} & \multirow{2}{*}{$\begin{array}{c}\text { 总数量 }\left(10^{5} \cdot \mathrm{g}^{-1} \text { 干土 }\right) \\
\text { Total abundance } \\
\left(10^{5} \cdot \mathrm{g}^{-1} \text { dry soil }\right)\end{array}$} & \multicolumn{2}{|c|}{ 细菌 Bacteria } & \multicolumn{2}{|c|}{ 放线菌 Actinomyces } & \multicolumn{2}{|c|}{ 真菌 Fungi } \\
\hline & & & $\begin{array}{c}\text { 数量 }\left(10^{5} \cdot \mathrm{g}^{-1} \text { 干土 }\right) \\
\text { Abundance } \\
\left(10^{5} \cdot \mathrm{g}^{-1} \text { dry soil }\right)\end{array}$ & $\begin{array}{c}\text { 比例 } \\
\text { Proportion } \\
(\%)\end{array}$ & $\begin{array}{c}\text { 数量 }\left(10^{5} \cdot \mathrm{g}^{-1} \text { 干土 }\right) \\
\text { Abundance } \\
\left(10^{5} \cdot \mathrm{g}^{-1} \text { dry soil }\right)\end{array}$ & $\begin{array}{c}\text { 比例 } \\
\text { Proportion } \\
(\%)\end{array}$ & $\begin{array}{c}\text { 数量 }\left(10^{5} \cdot \mathrm{g}^{-1} \text { 干土 }\right) \\
\text { Abundance } \\
\left(10^{5} \cdot \mathrm{g}^{-1} \text { dry soil }\right)\end{array}$ & $\begin{array}{c}\text { 比例 } \\
\text { Proportion } \\
(\%)\end{array}$ \\
\hline \multirow{5}{*}{$\begin{array}{l}\text { 4月 } \\
\text { April }\end{array}$} & $\mathrm{RG}$ & 12.02 & $11.81 \pm 0.58^{\mathrm{a}}$ & 98.22 & $1.75 \pm 1.21^{b}$ & 1.46 & $0.03 \pm 2.91^{b}$ & 0.32 \\
\hline & LG & 12.15 & $11.51 \pm 1.73^{\mathrm{a}}$ & 94.67 & $1.99 \pm 3.53^{\mathrm{b}}$ & 1.64 & $0.44 \pm 1.76^{\mathrm{c}}$ & 3.69 \\
\hline & NG & 19.39 & $19.19 \pm 4.26^{\mathrm{c}}$ & 98.94 & $1.55 \pm 1.15^{\mathrm{a}}$ & 0.80 & $0.04 \pm 1.76^{\mathrm{b}}$ & 0.26 \\
\hline & $\mathrm{CR}$ & 14.55 & $13.69 \pm 1.73^{\mathrm{b}}$ & 94.24 & $8.26 \pm 5.24^{\mathrm{c}}$ & 5.68 & $0.01 \pm 0.33^{\mathrm{a}}$ & 0.08 \\
\hline & RG & 16.46 & $16.08 \pm 1.64^{b}$ & 98.03 & $3.33 \pm 1.53^{\mathrm{a}}$ & 1.66 & $0.04 \pm 1.26^{\mathrm{a}}$ & 0.31 \\
\hline \multirow{4}{*}{$\begin{array}{l}\text { 5月 } \\
\text { May }\end{array}$} & LG & 13.36 & $12.69 \pm 2.09^{\mathrm{a}}$ & 95.98 & $4.06 \pm 3.98^{\mathrm{ab}}$ & 1.83 & $0.03 \pm 2.02^{b}$ & 2.19 \\
\hline & NG & 18.04 & $17.65 \pm 4.51^{\mathrm{b}}$ & 98.65 & $3.21 \pm 3.69^{\mathrm{a}}$ & 0.99 & $0.06 \pm 2.69^{\mathrm{a}}$ & 0.36 \\
\hline & $\mathrm{CR}$ & 14.53 & $13.58 \pm 2.94^{\mathrm{a}}$ & 94.41 & $6.59 \pm 3.02^{\mathrm{c}}$ & 5.19 & $0.03 \pm 1.05^{\mathrm{b}}$ & 0.40 \\
\hline & RG & 15.56 & $15.08 \pm 3.07^{\mathrm{b}}$ & 96.42 & $4.79 \pm 3.64^{\mathrm{b}}$ & 2.63 & $0.01 \pm 1.34^{\mathrm{a}}$ & 0.95 \\
\hline \multirow{4}{*}{$\begin{array}{l}\text { 6月 } \\
\text { June }\end{array}$} & LG & 13.22 & $12.47 \pm 1.33^{\mathrm{a}}$ & 95.21 & $2.51 \pm 4.01^{\mathrm{a}}$ & 2.79 & $0.04 \pm 3.17^{\mathrm{c}}$ & 2.00 \\
\hline & NG & 16.98 & $16.43 \pm 2.77^{\mathrm{b}}$ & 95.83 & $5.03 \pm 2.79^{b}$ & 2.40 & $0.02 \pm 5.69^{b}$ & 1.77 \\
\hline & $\mathrm{CR}$ & 14.21 & $13.24 \pm 2.50^{\mathrm{a}}$ & 93.29 & $4.91 \pm 3.84^{\mathrm{b}}$ & 3.42 & $0.03 \pm 3.89^{c}$ & 3.29 \\
\hline & RG & 16.86 & $15.59 \pm 4.11^{\mathrm{c}}$ & 92.50 & $8.34 \pm 1.31^{\mathrm{b}}$ & 4.93 & $0.04 \pm 2.08^{\mathrm{a}}$ & 2.57 \\
\hline \multirow{4}{*}{$\begin{array}{c}\text { 7月初 } \\
\text { Early of July }\end{array}$} & LG & 10.44 & $9.43 \pm 2.91^{\mathrm{a}}$ & 86.88 & $5.16 \pm 4.53^{\mathrm{a}}$ & 7.12 & $0.05 \pm 2.68^{\mathrm{a}}$ & 6.00 \\
\hline & NG & 17.51 & $16.49 \pm 3.19^{c}$ & 93.92 & $5.99 \pm 6.07^{\mathrm{a}}$ & 3.57 & $0.04 \pm 4.16^{\mathrm{a}}$ & 2.51 \\
\hline & $\mathrm{CR}$ & 13.83 & $12.91 \pm 2.18^{\mathrm{b}}$ & 90.44 & $8.48 \pm 2.71^{b}$ & 6.18 & $0.05 \pm 0.88^{\mathrm{a}}$ & 3.38 \\
\hline & RG & 12.88 & $11.84 \pm 3.39^{\mathrm{b}}$ & 89.46 & $7.38 \pm 3.62^{b}$ & 7.75 & $0.03 \pm 2.44^{\mathrm{a}}$ & 2.79 \\
\hline \multirow{4}{*}{$\begin{array}{c}\text { 7月末 } \\
\text { End of July }\end{array}$} & LG & 5.18 & $5.41 \pm 6.88^{\mathrm{a}}$ & 87.18 & $3.89 \pm 2.56^{\mathrm{a}}$ & 6.25 & $0.04 \pm 5,78^{\mathrm{a}}$ & 6.57 \\
\hline & NG & 17.64 & $16.31 \pm 2.87^{\mathrm{c}}$ & 92.47 & $7.22 \pm 3.39^{b}$ & 4.11 & $0.06 \pm 0.88^{b}$ & 3.42 \\
\hline & $\mathrm{CR}$ & 12.66 & $11.49 \pm 2.68^{b}$ & 90.56 & $8.67 \pm 1.81^{\mathrm{c}}$ & 6.98 & $0.03 \pm 2.37^{\mathrm{a}}$ & 2.46 \\
\hline & RG & 12.16 & $11.46 \pm 11.55^{\mathrm{b}}$ & 93.87 & $5.79 \pm 5.41^{\mathrm{b}}$ & 4.99 & $0.01 \pm 1.73^{\mathrm{a}}$ & 1.14 \\
\hline \multirow{4}{*}{$\begin{array}{c}\text { 8月 } \\
\text { August }\end{array}$} & LG & 8.79 & $8.21 \pm 8.13^{\mathrm{a}}$ & 90.53 & $4.71 \pm 5.17^{\mathrm{b}}$ & 7.75 & $0.01 \pm 2.57^{\mathrm{a}}$ & 1.72 \\
\hline & NG & 11.96 & $11.58 \pm 1.58^{\mathrm{b}}$ & 96.77 & $2.67 \pm 4.01^{\mathrm{a}}$ & 2.27 & $0.01 \pm 1.53^{\mathrm{a}}$ & 0.96 \\
\hline & $\mathrm{CR}$ & 10.51 & $9.60 \pm 0.70^{\mathrm{a}}$ & 89.78 & $7.91 \pm 3.08^{\mathrm{c}}$ & 8.81 & $0.01 \pm 2.35^{\mathrm{a}}$ & 1.41 \\
\hline & RG & 15.61 & $15.14 \pm 4.57^{\mathrm{b}}$ & 97.16 & $4.21 \pm 2.97^{\mathrm{b}}$ & 2.56 & $0.04 \pm 4.82^{\mathrm{a}}$ & 0.28 \\
\hline 9月 & LG & 12.92 & $12.71 \pm 3.94^{\mathrm{b}}$ & 98.40 & $1.72 \pm 2.54^{\mathrm{a}}$ & 1.33 & $0.04 \pm 0.88^{\mathrm{a}}$ & 0.27 \\
\hline \multirow[t]{2}{*}{ September } & NG & 10.51 & $9.77 \pm 7.97^{\mathrm{a}}$ & 86.48 & $6.98 \pm 2.21^{\mathrm{c}}$ & 12.59 & $0.04 \pm 1.47^{\mathrm{a}}$ & 0.93 \\
\hline & $\mathrm{CR}$ & 7.74 & $7.15 \pm 2.78^{\mathrm{a}}$ & 82.93 & $5.65 \pm 1.81^{\mathrm{d}}$ & 16.53 & $0.03 \pm 1.22^{\mathrm{a}}$ & 0.54 \\
\hline
\end{tabular}

$\mathrm{CR}$, 农田; LG, 豆禾混播草地; NG, 围封草地; RG, 补播草地。同列不同小写字母表示差异显著 $(p<0.05)$ 。

CR, cropland; LG, legume-grass mixture; NG, natural grassland; RG, reseeding grassland. Different lowercase letters in the same column indicate significant differences $(p<0.05)$.

www.plant-ecology.com 
各样地总微生物数量存在一定的季节变化, 表 现为RG随时间的变化数量不断上升并在 7 月初达到 最大值 $\left(16.86 \times 10^{5} \cdot \mathrm{g}^{-1}\right.$ 干土 $)$, 而最小值出现在 4 月 初, 温度较低可能是影响微生物生物量较低的原因; LG总微生物数量随时间的变化有先增加后降低再 增加的趋势, 其最大值出现在 5 月 $\left(13.36 \times 10^{5} \cdot \mathrm{g}^{-1}\right.$ 干 土), 而最小值出现在7月初 $\left(5.18 \times 10^{5} \cdot \mathrm{g}^{-1}\right.$ 干土 $)$; $\mathrm{NG}$ 随时间变化出现先降低后增加再降低的趋势, 其最 小值出现在 9 月 $\left(10.51 \times 10^{5} \cdot \mathrm{g}^{-1}\right.$ 干土 $) ; \mathrm{CR}$ 总微生物 生物量从翻耕后随时间的变化始终呈明显的递减趋 势, 最大值出现在 4 月 $\left(12.02 \times 10^{5} \cdot \mathrm{g}^{-1}\right.$ 干土 $)$, 最小值 出现在 9 月 $\left(7.74 \times 10^{5} \cdot \mathrm{g}^{-1}\right.$ 干土 $)$ 。微生物各类群受土 地利用方式的影响有所不同(表3), 不同类群微生物
随时间的变化而发生变化, 细菌的数量在各类群中 占绝对多数, 其变化可以反映土地利用方式变化后, 土壤微生物生物量的变化, 本研究中 $\mathrm{RG}$ 和 $\mathrm{LG}$ 在生 长季前期和后期均占 $90 \%$ 以上，而生长季旺期占 $80 \%$, 其变化与土壤温度的变化相反, 与土壤含水 量的变化趋势相似。 $\mathrm{NG}$ 和CR则表现为在生长季的 前期和中期, 其细菌在总微生物群落中均占 $90 \%$ 以 上, 而到生长季后期则在 $80 \%$ 以上 $90 \%$ 以下, 其变 化与土壤温度变化相似。为探明各区系对土壤呼吸 的影响以及土壤呼吸变化与土壤微生物协同变化的 趋势, 将单位体积土壤细菌、真菌和放线菌数量与 相应样地土壤呼吸速率进行拟合分析, 如图5所示, $\mathrm{RG}$ 土壤呼吸与放线菌呈显著的线性相关 $(p<0.05)$

表3 不同土地利用方式下各样地土壤微生物数量和微生物生物量碳比较(平均值土标准偏差, $n=3$ )

Table 3 Soil microflora and microbial biomass carbon in plots with different land use types ( $\operatorname{mean} \pm S D, n=3)$

\begin{tabular}{|c|c|c|c|c|}
\hline 指标 Index & LG & $\mathrm{RG}$ & NG & CR \\
\hline 细菌 Bacteria $\left(10^{5} \cdot \mathrm{g}^{-1}\right.$ dry soil $)$ & $14.17 \pm 3.95^{\mathrm{bc}}$ & $10.31 \pm 3.91^{\mathrm{a}}$ & $15.02 \pm 4.93^{\mathrm{c}}$ & $11.25 \pm 3.90^{\mathrm{ab}}$ \\
\hline 放线菌 Actinomyces $\left(10^{5} \cdot \mathrm{g}^{-1}\right.$ dry soil $)$ & $5.34 \pm 24.42^{\mathrm{a}}$ & $3.55 \pm 20.18^{\mathrm{a}}$ & $4.91 \pm 30.91^{\mathrm{ab}}$ & $7.13 \pm 19.87^{b}$ \\
\hline 真菌 Fungi $\left(10^{5} \cdot \mathrm{g}^{-1}\right.$ dry soil $)$ & $0.02 \pm 16.18^{\mathrm{a}}$ & $0.03 \pm 18.42^{\mathrm{b}}$ & $0.02 \pm 23.01^{\mathrm{b}}$ & $0.02 \pm 19.45^{\mathrm{b}}$ \\
\hline 微生物生物量碳 Microbial biomass carbon $\left(\mathrm{mg} \cdot \mathrm{kg}^{-1}\right)$ & $82.15 \pm 26.61^{\mathrm{a}}$ & $82.12 \pm 29.26^{\mathrm{a}}$ & $97.41 \pm 32.92^{\mathrm{b}}$ & $97.72 \pm 35.79^{b}$ \\
\hline
\end{tabular}

$\mathrm{CR}$, 农田; $\mathrm{LG}$, 豆禾混播草地; $\mathrm{NG}$, 围封草地; RG, 补播草地。同行不同小写字母表示差异显著 $(p<0.05)$ 。

CR, cropland; LG, legume-grass mixture; NG, natural grassland; RG, reseeding grassland. Different lowercase letters in the same row indicate significant differences $(p<0.05)$.
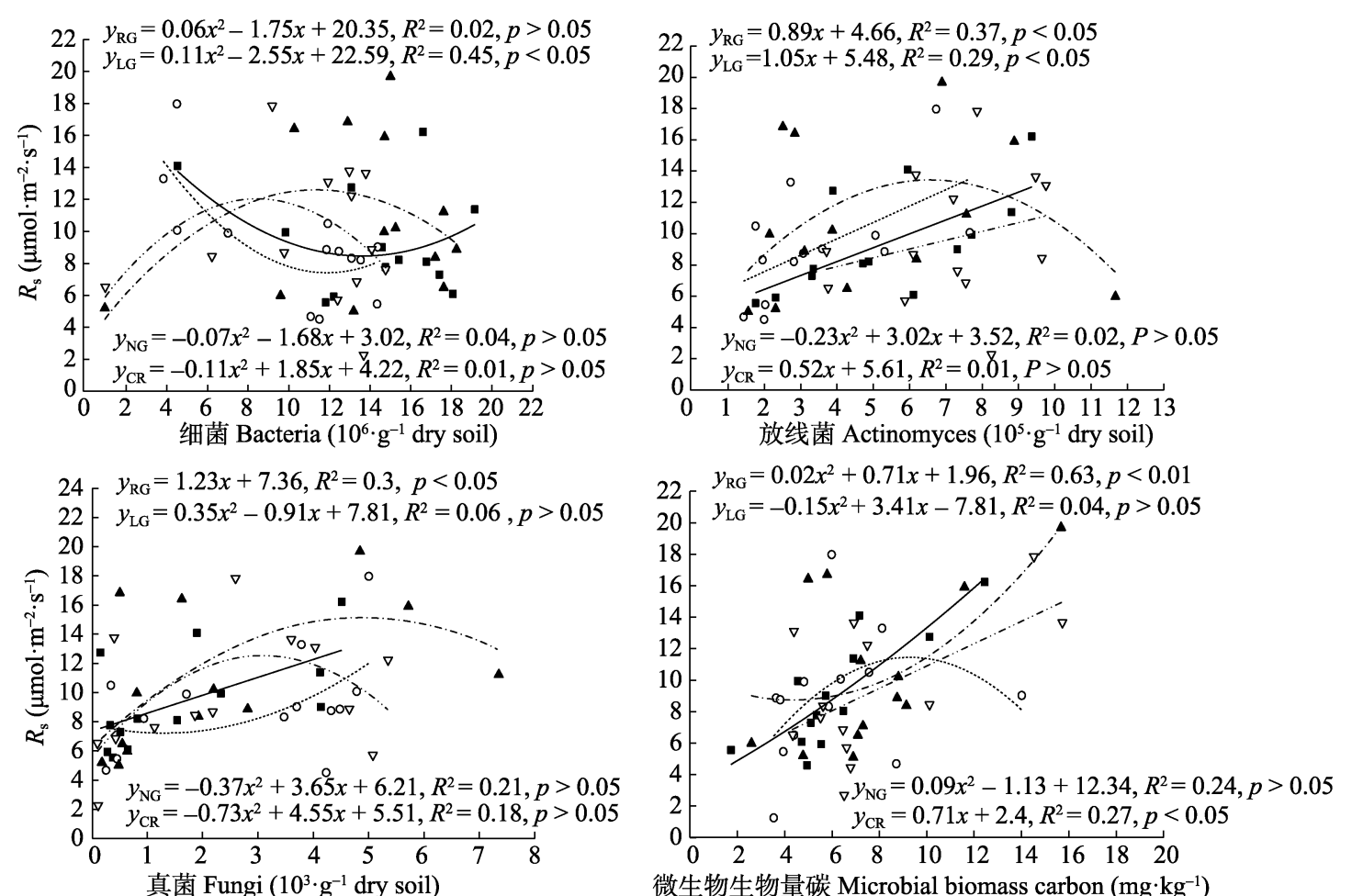

微生物生物量碳 Microbial biomass carbon $\left(\mathrm{mg} \cdot \mathrm{kg}^{-1}\right)$

- $\mathrm{RG} \quad \mathrm{LG} \triangle \mathrm{NG} \quad \nabla \mathrm{CR} \quad \mathrm{RG} \quad \ldots \ldots \ldots \mathrm{LG} \quad \ldots \mathrm{NG} \quad \ldots-\ldots \mathrm{CR}$

图5 不同利用方式下土壤呼吸速率 $\left(R_{\mathrm{s}}\right)$ 与微生物区系、微生物生物量碳的相关关系(平均值土标准偏差)。 $\mathrm{CR}$, 农田; $\mathrm{LG}$, 豆禾 混播草地; NG, 围封草地; RG, 补播草地。

Fig. 5 The relationship between soil respiration $\operatorname{rate}\left(R_{\mathrm{S}}\right)$ and microflora, microbial biomass carbon in four plots with different land use types (mean $\pm S D$ ). $\mathrm{CR}$, cropland; LG, legume-grass mixture; NG, natural grassland; RG, reseeding grassland. 
与细菌和真菌的相关性不显著 $(p>0.05)$ 。 LG土壤呼 吸与细菌和放线菌呈显著线性相关 $(p<0.05)$ 与真菌 无线性相关; $\mathrm{NG}$ 与 $\mathrm{CR}$ 的土壤呼吸与各微生物数量 均无显著线性关系。

不同利用方式下土壤微生物生物量碳如图6所 示, 各处理随季节的温度和湿度的变化有较明显的 变化, 但各处理微生物生物量碳最大值和最小值出 现的时间有所不同, RG的最大值出现在 2015 年 8 月 和2016年6月, 最小值出现在2016年6月初和2015年 5月底。LG的最大值出现在2015年7月初和2016年9月, 最小值出现在2015年9月和2016年4月; NG的最大值 出现在 2015年6月和2016年7月底, 最小值出现在 2015年8月和2016年9月; CR最小值出现在2015年7月 初和2016年6月初, 最大值出现在2015年7月底和2016 年8月。单因素方差分析的结果(表3)表明, LG与 $N G$ 和 $\mathrm{CR}$ 存在显著差异, $\mathrm{RG}$ 与 $\mathrm{NG}$ 和 $\mathrm{CR}$ 也存在显著差异, 其余差异不明显; 其平均值为 $\mathrm{CR}>\mathrm{NG}>\mathrm{LG}>\mathrm{RG}$ 。

微生物生物量碳表征微生物的总量, 各样地植 被结构不同, 土壤表面覆盖度不同, 使土壤温度和 湿度存在差异, 从而影响微生物碳的变化。各样地 土壤呼吸速率与微生物生物量碳拟合分析(图5)显 示, $\mathrm{RG}$ 与 $\mathrm{CR}$ 的土壤呼吸速率与微生物生物量碳显 著线性相关 $(p<0.05)$, 其中 CR 达到极显著 $(p<$ $0.01), \mathrm{LG}$ 与 NG相关性不明显。

\section{4 土壤酶活性变化对土壤呼吸的影响}

不同利用方式下土壤各时期酶活性如图7所示, 各样地各酶活性随季节的变化呈现一定的变化; 土 壤过氧化氢酶在2015年, RG、LG、NG、CR均呈现 先增加后降低的趋势, 在2016年, LG与 $N G$ 呈现由 低到高再到低的过程, RG表现为先增加后降低的趋 势, $\mathrm{NG}$ 翻耕后过氧化氢酶出现明显降低, 各样地两 年监测期过氧化氢酶平均值大小为 $\mathrm{CR}>\mathrm{NG}>$ $\mathrm{RG}>\mathrm{LG}$; 脲酶活性 RG、 LG与 $\mathrm{NG}$ 在两年生长季内 均先增加后降低, CR则在翻耕后酶活性降低, 在生 长季旺期出现极低值, 两年脲酶活性平均值由大到 小为 $\mathrm{CR}>\mathrm{NG}>\mathrm{LG}>\mathrm{RG}$; 蔗糖酶呈现明显的季节 变化, 均在生长季旺期达到最大值, 其大小为 $\mathrm{CR}>$ $\mathrm{NG}>\mathrm{RG}>\mathrm{LG}$ 。蛋白酶生长季初期和生长季末期变 化都较小, 在生长季旺期变化较为剧烈, 其大小为 $\mathrm{CR}>\mathrm{NG}>\mathrm{LG}>\mathrm{RG}$ (表4)。

将各样地土壤呼吸与土壤酶活性进行拟合相关 分析(图8), 土壤过氧化氢酶和脲酶与土壤呼吸速率 拟合显示, 各样地拟合参数均较低, 且相关性均未 达到显著水平 $(p>0.05)$; 将蛋白酶与土壤呼吸速率 线性拟合显示，除 $\mathrm{NG}$ 相关性达到显著水平 $(p<$ $0.05)$, 其余各样地均未达到显著; 将蔗糖酶与土壤 呼吸速率拟合显示, 除 $\mathrm{LG}$ 未达到显著水平 $(p>$ $0.05)$, 其余各样地均达到显著水平。

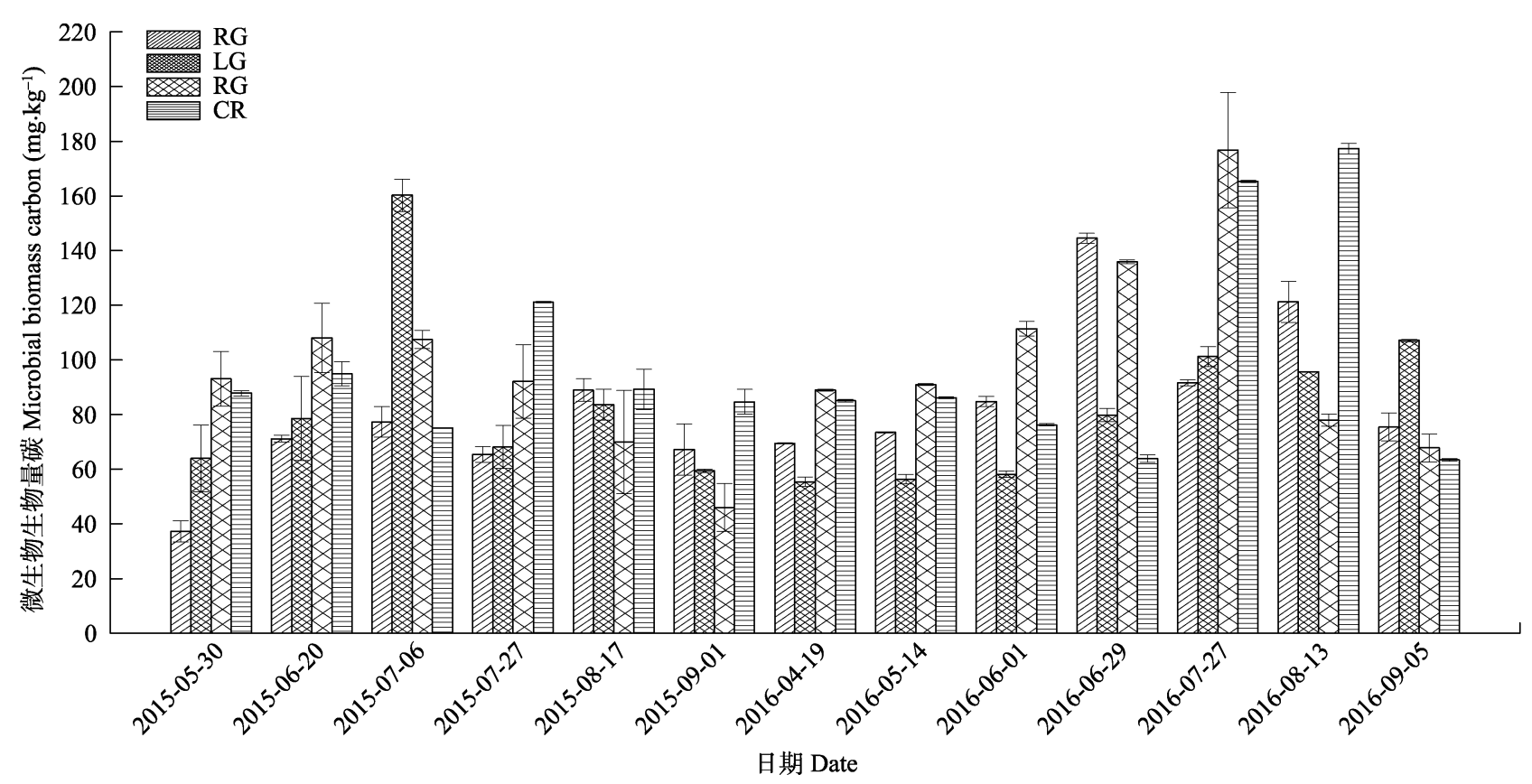

图6 不同利用方式下土壤微生物生物量碳(平均值标准偏差)。CR, 农田; LG, 豆禾混播草地; NG, 围封草地; RG, 补播草地。 Fig. 6 Soil microbial biomass carbon in four plots with different land use types (mean $\pm S D$ ). CR, cropland; LG, legume-grass mixture; NG, natural grassland; RG, reseeding grassland.

www.plant-ecology.com 


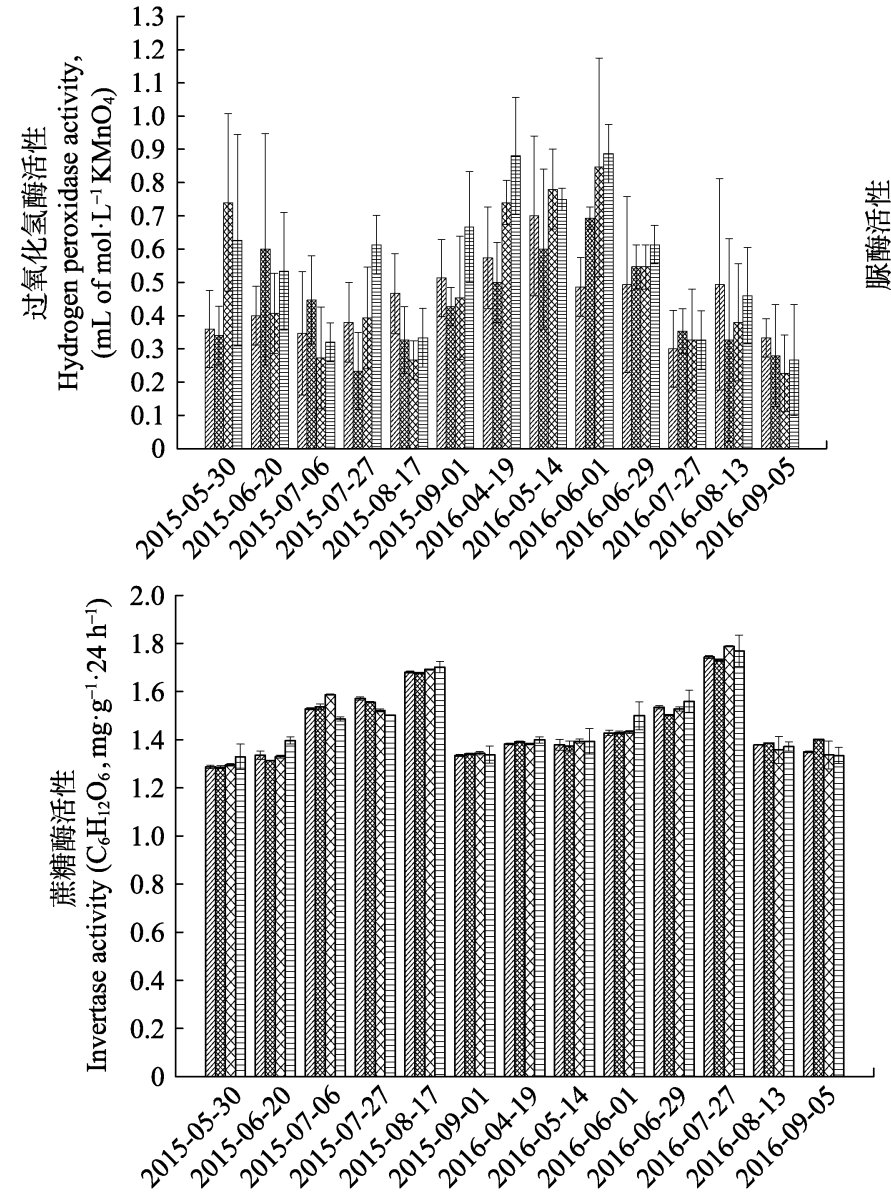

日期 Date
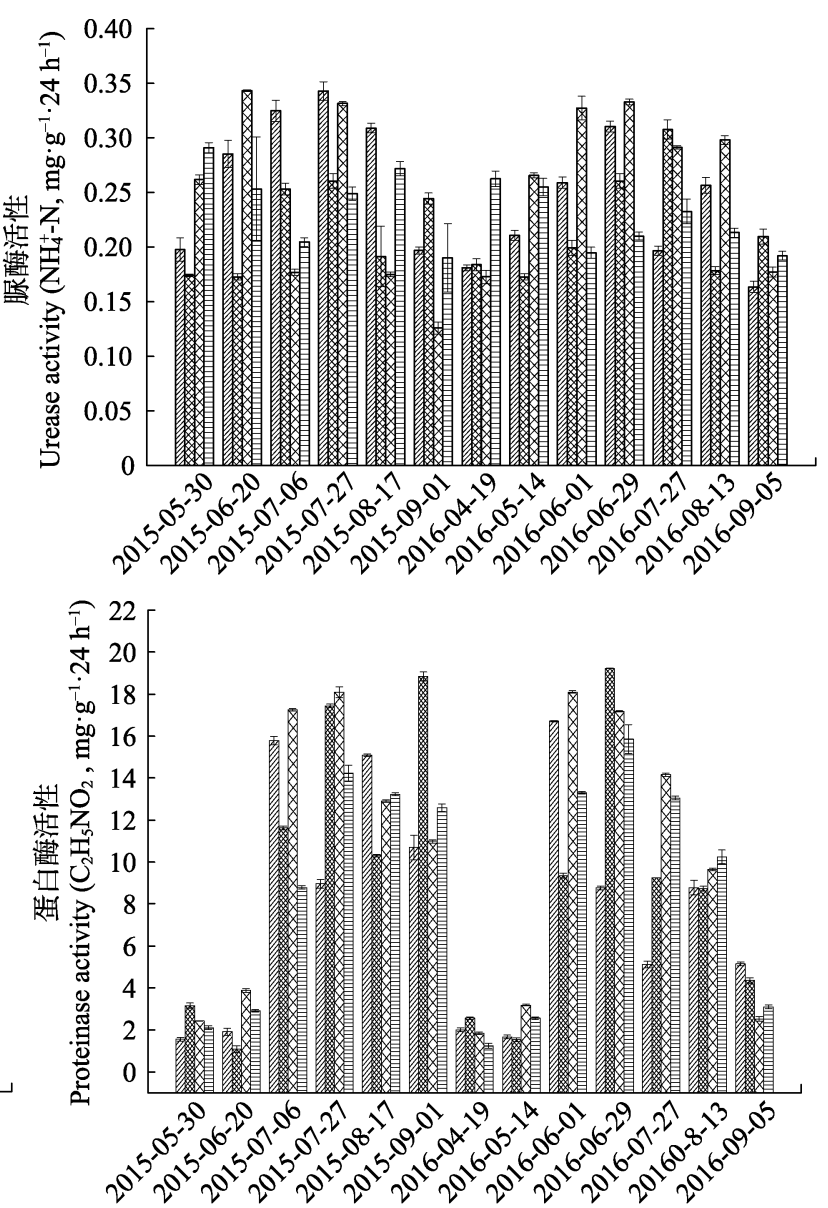

日期 Date

图7 不同利用方式草地土壤酶活性的变化(平均值土标准偏差)。CR, 农田; $\mathrm{LG}$, 豆禾混播草地; NG, 围封草地; RG, 补播草地。 Fig. 7 Soil enzyme activities in four plots with different land use types (mean $\pm S D$ ). CR, cropland; LG, legume-grass mixture; NG, natural grassland; RG, reseeding grassland.

表4 不同土地利用方式下土壤酶活性各样地酶活性比较(平均值土标准偏差, $n=3$ )

Table 4 Comparison of soil enzyme activity among four plots with different land use types (mean $\pm S D, n=3$ )

\begin{tabular}{ccccc}
\hline $\begin{array}{c}\text { 样地 } \\
\text { Plot }\end{array}$ & $\begin{array}{c}\text { 过氧化氢酶 Hydrogen peroxidase } \\
\left(\mathrm{mL} \text { of mol } \cdot \mathrm{L}^{-1} \mathrm{KMnO}_{4}\right)\end{array}$ & $\begin{array}{c}\text { 腿酶 Urease } \\
\left(\mathrm{NH}_{4}^{+} \mathrm{N}, \mathrm{mg} \cdot \mathrm{g}^{-1} \cdot 24 \mathrm{~h}^{-1}\right)\end{array}$ & $\begin{array}{c}\text { 蔗糖酶 Invertase } \\
\left(\mathrm{C}_{6} \mathrm{H}_{12} \mathrm{O}_{6}, \mathrm{mg} \cdot \mathrm{g}^{-1} \cdot 24 \mathrm{~h}^{-1}\right)\end{array}$ & $\begin{array}{c}\text { 蛋白酶 Proteinase } \\
\left(\mathrm{C}_{2} \mathrm{H}_{5} \mathrm{NO}_{2}, \mathrm{mg}^{-1} \cdot \mathrm{g}^{-1} \cdot 24 \mathrm{~h}^{-1}\right)\end{array}$ \\
\hline $\mathrm{RG}$ & $0.45 \pm 0.11^{\mathrm{a}}$ & $0.22 \pm 0.06^{\mathrm{a}}$ & $1.45 \pm 0.14^{\mathrm{a}}$ & $7.86 \pm 5.53^{\mathrm{a}}$ \\
$\mathrm{LG}$ & $0.44 \pm 0.14^{\mathrm{a}}$ & $0.23 \pm 0.04^{\mathrm{a}}$ & $1.46 \pm 0.13^{\mathrm{a}}$ & $8.71 \pm 6.43^{\mathrm{a}}$ \\
$\mathrm{NG}$ & $0.49 \pm 0.22^{\mathrm{ab}}$ & $0.25 \pm 0.07^{\mathrm{a}}$ & $1.46 \pm 0.15^{\mathrm{a}}$ & $9.04 \pm 6.61^{\mathrm{a}}$ \\
$\mathrm{CR}$ & $0.64 \pm 0.29^{\mathrm{b}}$ & $0.25 \pm 0.03^{\mathrm{a}}$ & $1.47 \pm 0.14^{\mathrm{a}}$ & $10.17 \pm 5.48^{\mathrm{a}}$ \\
\hline
\end{tabular}

$\mathrm{CR}$, 农田; $\mathrm{LG}$, 豆禾混播草地; $\mathrm{NG}$, 围封草地; $\mathrm{RG}$, 补播草地。同行不同小写字母表示差异显著 $(p<0.05)$ 。

$\mathrm{CR}$, cropland; LG, legume-grass mixture; NG, natural grassland; RG, reseeding grassland. Different lowercase letters in the same row indicate significant differences $(p<0.05)$.

\section{3 讨论和结论}

\section{1 不同土地利用方式下土壤呼吸特征及其对水} 热因子的响应

土壤呼吸受自然环境和人为活动干扰的共同影 响, 不同气候环境、土壤环境和地上植被都会影响 土壤呼吸 $\mathrm{CO}_{2}$ 的产生量(刘伟等, 2011)。本研究表明, 在土地利用方式变化后, 土壤温度变化表现为 $L G>$
$\mathrm{RG}>\mathrm{NG}>\mathrm{CR}$, 土壤含水量的变化为 $\mathrm{CR}>\mathrm{NG}>$ $R G>L G$, 土壤呼吸速率年平均值为: $N G>R G>$ $\mathrm{CR}>\mathrm{LG}$; 较高的温度可能抑制豆禾混播草地土壤 呼吸, 使其土壤呼吸速率最低; 农田由于灌溉的缘 故, 保持较低的温度和较高的土壤含水量, 因此抑 制土壤呼吸 $\mathrm{CO}_{2}$ 排放; 补播草地的土壤温度低于混 播草地、土壤含水量高于混播草地, 平均土壤呼吸 速率也高于豆禾混播草地; 农田的土壤呼吸速率 


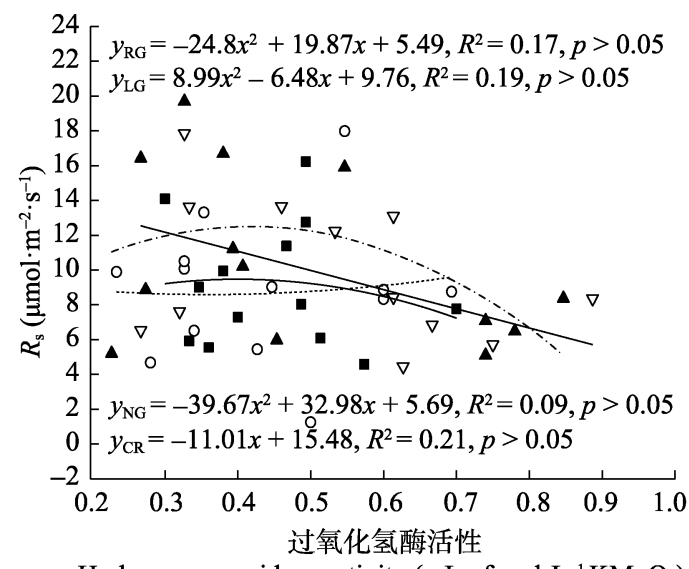

Hydrogen peroxidase activity $\left(\mathrm{mL}\right.$ of $\left.\mathrm{mol} \cdot \mathrm{L}^{-1} \mathrm{KMnO}_{4}\right)$

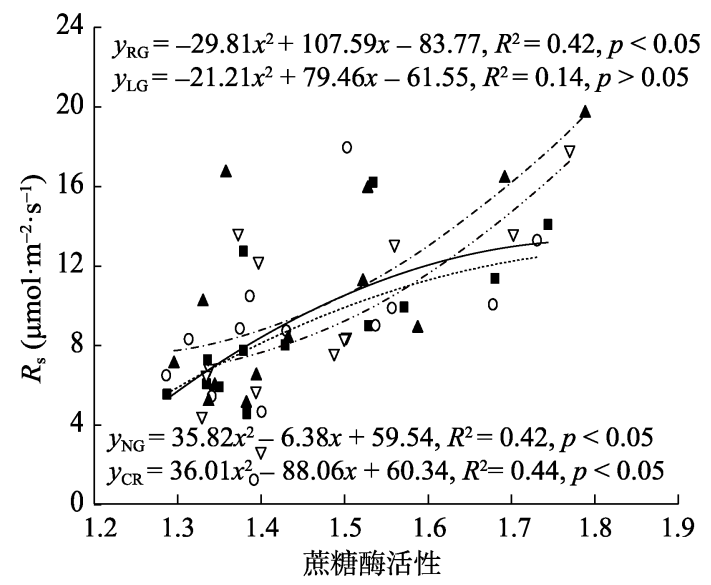

Invertase activity $\left(\mathrm{C}_{6} \mathrm{H}_{12} \mathrm{O}_{6}, \mathrm{mg} \cdot \mathrm{g}^{-1} \cdot 24 \mathrm{~h}^{-1}\right)$

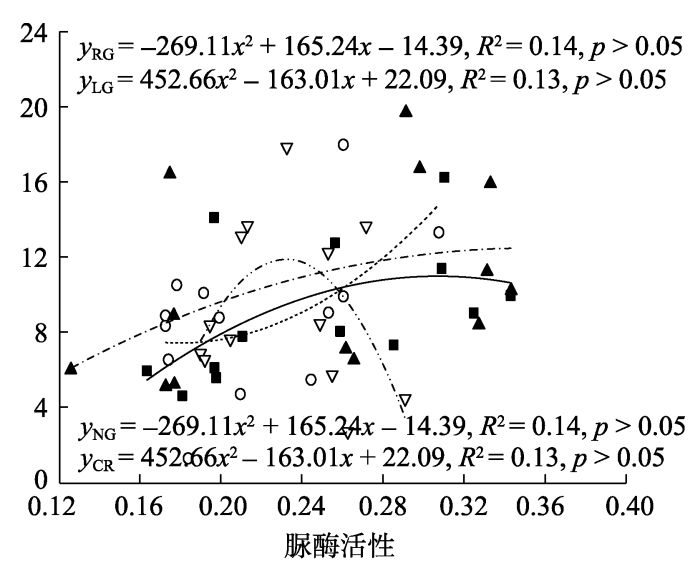

Urease activity $\left(\mathrm{NH}_{4}^{+}-\mathrm{N}, \mathrm{mg} \cdot \mathrm{g}^{-1} \cdot 24 \mathrm{~h}^{-1}\right)$

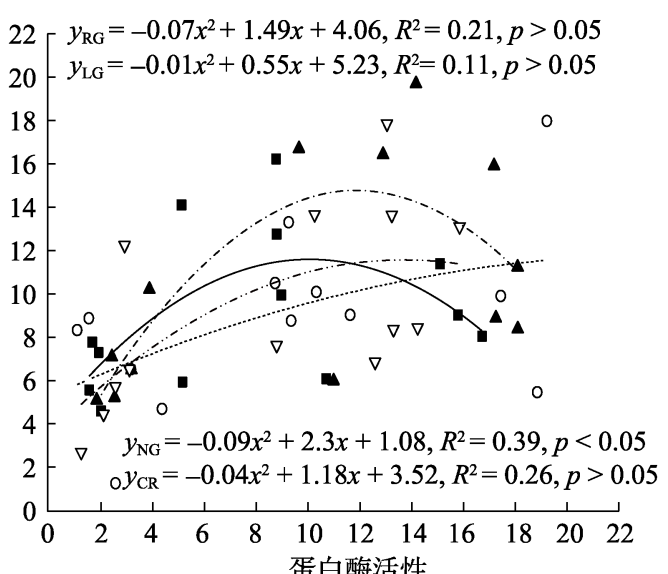

Proteinase activity $\left(\mathrm{C}_{2} \mathrm{H}_{5} \mathrm{NO}_{2}, \mathrm{mg} \cdot \mathrm{g}^{-1} \cdot 24 \mathrm{~h}^{-1}\right)$

- RG $\circ \mathrm{LG} \triangle \mathrm{NG} \nabla \mathrm{CR}-\mathrm{RG}$ .... LG $\quad$-..- NG $\quad$-...... CR

图8 不同土地利用方式下各样地土壤呼吸速率 $\left(R_{\mathrm{s}}\right)$ 与土壤酶活性的相关关系。 $\mathrm{CR}$, 农田; $\mathrm{LG}$, 豆禾混播草地; $\mathrm{NG}$, 围封草地; $\mathrm{RG}$, 补播草地。

Fig. 8 The relationship between soil respiration $\operatorname{rate}\left(R_{\mathrm{s}}\right)$ and enzymatic activity in four plots with different land use types. CR, cropland; LG, legume-grass mixture; NG, natural grassland; RG, reseeding grassland.

低于围封草地。这与郭慧敏等(2014)的研究结果不同, 其原因是本试验样地土壤温度和土壤含水量有关: 本区域常年雨水充足, 土壤水分含量较高, 当土壤 含水量饱和后，就会抑制土壤呼吸。李文等(2015) 也报道了高寒草甸草原土壤质量含水量对土壤呼吸 速率的影响存在一个临界值, $30 \%$ 左右为临界值, 在此之前二者呈正相关关系, 此后呈负相关关系。 另外, 各处理样地的土壤呼吸速率的季节变化表现 为: 在生长季初期和生长季末期均较低, 而在生长 旺季土壤呼吸速率达到一年中的最大值。这与温度 的季节变化相一致, 因此温度的变化仍然是土壤呼 吸变化的重要决定因素。

影响土壤呼吸的主要因子是所在区域的环境因 子, 特别是温度和水分(元伟伟等, 2012)。本研究发 现, 各处理 $5 \mathrm{~cm}$ 土壤温度与土壤呼吸指数拟合除农 田不显著外, 其余均达到显著水平; 就拟合效果而
言, 围封草地土壤呼吸速率与温度的拟合效果最好 $\left(R^{2}=0.59\right)$, 其次为补播草地 $\left(R^{2}=0.56\right)$ 和豆禾混播 草地 $\left(R^{2}=0.50\right)$, 而农田温度与土壤呼吸的拟合效 果最差, 这在一定程度上表明, 土壤利用方式变化 后, 补播草地和豆禾混播草地对温度变化较为敏感, 因为土壤呼吸通常对最限制它的因子产生响应，即 当土壤水分含量较低时, 土壤呼吸对温度的反应不 敏感; 当温度变低时, 土壤呼吸对土壤含水量的响 应不敏感(杨阳等, 2012)。农田的土壤呼吸速率与土 壤含水量和温度相关性均不明显, 说明含水量和温 度均不是其限制因子; 从土壤呼吸速率与土壤温度 和土壤湿度的拟合关系可以发现, 土地利用方式变 化后, 围封草地土壤呼吸速率与水热因子的拟合效 果均高于豆禾混播草地和补播草地。由此可以说明, 由于补播和人工重建使草地对水热因子的响应相对 围封草地均有所降低, 从而降低了草地对热量和水

www.plant-ecology.com 
分的依赖。有研究表明土壤水分与土壤呼吸呈线性 或二次正相关关系(李志刚和侯扶江, 2010; 王铭等, 2014), 但本研究发现土壤水分对土壤呼吸的影响 呈显著的线性负相关关系, 这与本区域降水充足, 土壤含水量较高有关; 在较为干旱的地区, 降水导 致的土壤含水量升高可能会提高土壤呼吸速率 (Zhang et al., 2015), 但本区域土壤水分长期充足, 水分减少反而能增加土壤呼吸速率, 因此土壤呼吸 速率与土壤温度表现为负相关。复合模型能很好地 解释水热对土壤呼吸速率的协同影响, 因此本研究 通过建立土壤呼吸与土壤温度和土壤水分间的复合 模型, 拟合关系结果表明, 土壤温度和水分共同解 释了土壤呼吸变异度的 $64 \%-89 \%$, 土壤温度和土壤 含水量是土壤呼吸的主要影响因素。

总体而言, $Q_{10}$ 与温度呈负相关关系, 即在温度 上升相同幅度下低温区比高温区有更大的 $Q_{10}$ (陈骐 等, 2014), 同时, 土壤干旱也会降低 $Q_{10}$ 值, 一定范 围内随着土壤含水量的增加, 土壤呼吸对温度的敏 感性也会增加(Kirschbaum, 2006)。土地利用方式的 变化引起上层植被和植被盖度的变化, 从而改变土 壤温度, 使 $Q_{10}$ 随之发生变化, $Q_{10}$ 变化则促使土壤 呼吸对温度的响应更加迅速; 本研究中土地利用方 式变化后, 围封草地的 $Q_{10}$ 数值最高, 其次是农田, 豆禾混播草地最低。农田和围封草地 $Q_{10}$ 较高, 也表 明在土地利用方式变化后其对温度变化的响应较为 敏感, 而温度对补播草地和豆禾混播草地的影响 较小。

\section{2 不同土地利用方式下土壤微生物特征及其与 土壤呼吸速率的关系}

土壤微生物是草地生态系统的重要组成部分, 其活动能力的强弱与植被类型、干扰强度、土壤肥 力等诸多因素有密切的关系(Su et al., 2005)。在本研 究中, 各样地土壤微生物数量以细菌占绝对优势, 放线菌次之, 真菌数量最少, 这与大多数学者的研 究结果(张文婷等, 2008; 张成霞和南志标, 2010)一 致。总微生物生物量则表现为 $\mathrm{NG}>\mathrm{RG}>\mathrm{CR}>\mathrm{LG}$, 这与两年监测期平均土壤呼吸排放速率大小完全一 致。本研究中细菌在微生物群落中占 $80 \%-90 \%$, 因 此各土地利用方式对细菌数量的影响也最大, 而细 菌的变化一定程度上也是土壤呼吸变化的主要原 因。本研究中各处理微生物生物量碳的大小为 $\mathrm{CR}>$ $\mathrm{NG}>\mathrm{LG}>\mathrm{RG}$, 微生物生物量碳含量的提高, 标志
着土壤微生物活性得到一定程度的改善, 可以促进 土壤团聚体的形成, 加快动植物残体的分解速度和 养分的转化进程, 微生物生物量的大小主要取决于 输入土壤的物质和质量(蒋德明等, 2006); 本研究结 果表明, 补播草地和农田的土壤呼吸速率与土壤微 生物生物量碳有密切关系, 说明微生物对这两种土 地利用方式的土壤呼吸速率有一定的影响。农田微 生物生物量碳的含量较高是由于农田翻耕和施肥, 且历年收割后秥秆还田导致微生物生物量碳增加。

\section{3 不同土地利用方式下土壤酶活性特征及其与 土壤呼吸的关系}

土壤酶活性的大小影响土壤中的生物学过程, 而土壤呼吸的大小反映了土壤中的生物学过程的强 弱(陈书涛等, 2016)。本研究各样地4种土壤酶活性 的高低均表现为农田最大、围封草地次之, 豆禾混 播草地和补播草地最小, 农田和围封草地土壤酶活 性的较高也在一定程度上解释了其土壤呼吸速率较 高的原因, 而补播草地和豆禾混播草地较低的土壤 酶活性也是其土壤呼吸速率较低的一个重要原因。 农田酶活性较高可能是由于本研究样地采用秥秆还 田的方式, 在一定程度上保持了土壤肥力, 为土壤 微生物提供了营养, 间接促进了土壤酶活性; 研究 表明增温、秸秆施用均会提高土壤微生物的数量和 活性(Rinnan et al., 2009; 孙建等, 2009; 王学娟等, 2014)。土壤呼吸与酶活性的线性相关分析表明: 蛋 白酶与围封草地的相关性达到显著水平, 蔗糖酶与 农田、围封草地和补播草地的土壤呼吸均有显著相 关性, 而豆禾混播草地与酶活性均无显著相关性。 土壤蔗糖酶能催化糖的水解过程, 与土壤碳循环过 程有关, 以往也有研究验证了土壤微生物呼吸与蔗 糖酶具有相关关系(吴静等, 2015)。蛋白酶是参与土 壤氮素循环的主要酶, 其活性大小直接影响土壤养 分, 从而影响土壤微生物呼吸速率的大小。

因此, 4种土地利用方式影响了天山北坡西段山 地草甸的水热和生物因素, 从而导致土壤呼吸速率 的改变。其中, 水热因素和温度敏感性 $\left(Q_{10}\right)$ 对围封 草地和农田土壤呼吸速率影响较大, 而对豆禾混播 草地和补播草地影响较小; 围封草地和农田也具有 较高的微生物生物量和土壤酶活性。故而, 退化的 山地草甸在不同土地利用方式下土壤呼吸速率表现 为围封草地 $>$ 补播草地 $>$ 农田 $>$ 豆禾混播草地, 即豆 禾混播草地和补播草地相对于围封草地和农田, 显 
著降低了土壤呼吸速率，提高了草地土壤的固碳能 力。因此在昭苏地区，对退化山地草甸的合理利用 和生态保护措施中, 建植人工草地和补播草地是较 好的选择。

\section{参考文献}

Anderson DW, Coleman DC (1985). The dynamics of organic matter in grassland soils. Journal of Soil \& Water Conservation, 40, 211-216.

Chen J, Cao JJ, Wei YL, Liu JH, Ma FL, Chen DC, Feng JY, Xia Y, Ceng Y (2014). Effect of grazing exclusion on soil respiration during the dormant season in alpine meadow grassland ecosystems on the northern shore of Qinghai Lake, China. Acta Prataculturae Sinica, 23(6), 78-86. [陈 瀷, 曹军骥, 魏永林, 刘吉宏, 马扶林, 陈迪超, 冯嘉 裕, 夏瑶, 岑燕 (2014). 青海湖北岸高寒草甸草原非生 长季土壤呼吸对温度和湿度的响应. 草业学报, 23(6), 78-86.]

Chen ST, Sang L, Zhang X, Hu ZH (2016). Effects of warming and straw application on soil respiration and enzyme activity in a winter wheat cropland. Environmental Science, 37, 703-709. [陈书涛, 桑琳, 张旭, 胡正华 (2016). 增温及 秸秆施用对冬小麦田土壤呼吸和酶活性的影响. 环境 科学, 37, 703-709.]

Flechard CR, Ambus P, Skiba U, Rees RM, Hensen A, van Amstel A, Raschi A (2007). Effects of climate and management intensity on nitrous oxide emissions in grassland systems across Europe. Agriculture, Ecosystems \& Environment, 121, 135-152.

Guan SY (1986). Soil Enzyme and Its Study Method. China Agriculture Press, Beijing. 320-344. [关松荫 (1986). 土 壤酶及其研究法. 农业出版社, 北京. 320-344.]

Guo HM, Zhang YY, Liu QF, Jiang JS, Li JC, Wang R, Li NN, Li RJ, Guo SL, Li CY (2014). Responses of soil respiration to land use changes in a semiarid region of Loess Plateau. Journal of Natural Resources, 29, 1686-1695. [郭慧 敏, 张彦军, 刘庆芳, 姜继韶, 李俊超, 王荵, 李娜娜, 李如剑, 郭胜利, 李春越 (2014). 黄土高原半干旱区土 壤呼吸对土地利用变化的响应. 自然资源学报, 29, 1686-1695.]

Guo MY, Zhao KT, You JC, Xu LJ, Wang LJ, Ja SJ (2012). Soil microbial characteristic and soil respiration in grassland under different use patterns. Acta Agrestia Sinica, 20(1)，42-48. [郭明英, 朝克图, 尤金成, 徐丽君, 王丽 娟, 贾淑杰 (2012). 不同利用方式下草地土壤微生物及 土壤呼吸特性. 草地学报, 20(1), 42-48.]

Hanson PJ, Edwards NT, Garten CT, Andrews JA (2000). Separating root and soil microbial contributions to soil respiration: A review of methods and observations. Bio- geochemistry, 48, 115-146.

Jiang DM, He SF, Cao CY, Toshio O, Li XH (2006). Effect of plowing and reseeding on soil physicochemical properties and biological activities of alkalized grassland in Horqin area. Chinese Journal of Grassland, 28(4), 18-23. [蒋德 明, 贺山峰, 曹成有, 押田敏雄, 李雪华 (2006). 翻耙 补播对科尔沁碱化草地土壤理化性质和生物活性的影 响. 中国草地学报, 28(4), 18-23.]

Kirschbaum MUF (2006). The temperature dependence of organicmatter decomposition-still a topic of debate. Soil Biology \& Biochemistry, 38, 2510-2518.

Lal R (2004). Soil carbon sequestration impacts on global climate change and food security. Science, 304, 1623.

Lal R, Kimble J, Follett R (1998). Land use and soil C pool in terrestrial ecosystems. In: Lal R, Kimbkle J, Follett R, Stewarteds BA eds. Management of Carbon Sequestration in Soil. CRC Press, Boca Raton.1-10.

Li W, Cao WX, Liu HD, Li XL, Xu CL, Shi SL, Feng J, Zhou CM (2015). Analysis of soil respiration under different grazing management patterns in the alpine meadow-steppe of the Qinghai-Tibet Plateau. Acta Prataculturae Sinica, 24(10)，22-32. [李文, 曹文侠, 刘皓栋, 李小龙, 徐长 林, 师尚礼, 冯今, 周传猛 (2015). 不同放牧管理模式 对高寒草甸草原土壤呼吸特征的影响. 草业学报, 24(10), 22-32.]

Li ZG, Hou FJ (2010). Analysis of soil respiration diurnal dynamics and factors influencing it in enclosed natural grasslands under different topographies in the Loess Plateau. Acta Prataculturae Sinica, 19(1), 42-49. [李志刚, 侯扶江 (2010). 黄土高原不同地形封育草地的土壤呼 吸日动态与影响因子分析. 草业学报, 19(1), 42-49.]

Liu HF, Wu X, Li Y, Li ZS, Liu GH (2014). Effects of land use change on greenhouse gas fluxes from soils: A review. Chinese Journal of Ecology, 33, 1960-1968. [刘慧峰, 伍 星, 李雅, 李宗善, 刘国华 (2014). 土地利用变化对土 壤温室气体排放通量影响研究进展. 生态学杂志, 33, 1960-1968.]

Liu JC, Li ZG, Li X (2014). Research of variations of soil respiration rate among different land use types in the Agro-pastoral Ecotone of North China. Journal of Inner Mongolia University for Nationalities, 29, 306-309. [刘季 骢, 李志刚, 李兴 (2014). 北方农牧交错带不同土地利 用方式下土壤呼吸速率探究. 内蒙古民族大学学报(自 然科学版), 29, 306-309.]

Liu W, Wang JM, Wang ZP (2011). Plant functional type effects on methane uptake by soils in typical grasslands of Inner Mongolia. Chinese Journal of Plant Ecology, 35, 275-283. [刘伟, 王继明, 王智平 (2011). 内蒙古典型 草原植物功能型对土壤甲烷吸收的影响. 植物生态学 报, 35, 275-283.]

www.plant-ecology.com 
Ning F, Xu Z, Shan GL (2008). Effects of disturbance ways on soil physical and chemical properties. Chinese Journal of Grassland, 30(4), 46-50. [宁发, 徐柱, 单贵莲 (2008). 干扰方式对典型草原土壤理化性质的影响. 中国草地 学报, 30(4), 46-50.]

Qi WW, Niu HS, Wang SP, Liu YJ, Zhang LR (2012). Simulation of effects of warming on carbon budget in alpine meadow ecosystem on the Tibetan Plateau. Acta Ecologica Sinica, 32, 1713-1722. [元伟伟, 牛海山, 汪诗平, 刘艳 杰, 张立荣 (2012). 增温对青藏高原高寒草甸生态系统 固碳通量影响的模拟研究. 生态学报, 32, 1713-1722.]

Raiesi F, Beheshti A (2014). Soil C turnover, microbial biomass and respiration, and enzymatic activities following range and conversion to wheat-alfalfa cropping in a semi-arid climate . Environmental Earth Sciienes, 72, 5073-5088.

Rinnan R, Stark S, Tolvanen A (2009). Responses of vegetation and soil microbial communities to warming and simulated herbivory in a subarctic heath. Journal of Ecology, 97, 788-800.

Sampson RN, Apps M, Brown S, Cole CV, Smith TM, Downing J, Ojima DS, Solomon AM, Heath LS, Wisniewski J (1993). Terrestrial biosphere carbon fluxes quantification of sinks and sources of $\mathrm{CO}_{2}$. Water, Air, and Soil Pollution, 70, 3-15.

Sparling GP, Shepherd TG, Kettles HA (1992). Changes in soil organic $\mathrm{C}$, microbial $\mathrm{C}$ and aggregate stability under continuous maize and cereal cropping, and after restoration to pasture in soils from the Manawatu Region, New Zealand. Soil \& Tillage Research, 24, 225-241.

Su YZ, Li YL, Cui J Y, Zhao WZ (2005). Influences of continuous grazing and livestock exclusion on soil properties in a degraded early grassland, Inner Mongolia, northern China. Catena, 59, 267-278.

Sun J, Liu M, Li LJ, Liu JH, Zhang XJ (2009). Influence of non-tillage and stubble on soil microbial biomass $\mathrm{C} / \mathrm{N}$ and enzyme activities in rain-fed field of Inner Mongolia. Acta Ecologica Sinica, 29, 5508-5515. [孙建, 刘苗, 李立军, 刘景辉, 张星杰 (2009). 免耕与留茬对土壤微生物生物 量C、N及酶活性的影响. 生态学报, 29, 5508-5515.]

Wang M, Liu YS, Li XJ, Zhang JT, Wang GD, Lu XR, Li XY (2014). Soil respiration dynamics and its controlling factors of typical vegetation communities on meadow steppes in the western Songnen Plain. Chinese Journal of Applied Ecology, 25, 45-52. [王铭, 刘兴士, 李秀军, 张继涛, 王 国栋, 鲁新荵, 李晓宇 (2014). 松嫩平原西部草甸草原 典型植物群落土壤呼吸动态及影响因素. 应用生态学 报, 25, 45-52.]

Wang XG, Zhu B, Wang YQ, Zheng XH (2007). Soil respiration and its sensitivity to temperature under different land use conditions. Acta Ecologica Sinica, 27, 1960-1968. [王
小国，朱波，王艳强，郑循华 (2007). 不同土地利用方 式下土壤呼吸及其温度敏感性. 生态学报, 27 , 1960-1968.]

Wang XJ (2013). Study on Reconstruction and Utilization of Grassland for Grazing. Master degree dissertation, Xinjiang Agricultural University, Ürümqi. [王雪娇 (2013). 放牧型 草地重建与利用研究. 硕士学位论文, 新疆农业大学, 乌鲁木齐.]

Wang XJ, Zhou YM, Wang XX, Jiang XJ, Han SJ (2014). Responses of soil enzymes in activity and soil microbes in biomass to warming in tundra ecosystem on Changbai Mountains. Acta Pedologica Sinica, 51, 166-175. [王学 娟, 周玉梅, 王秀秀, 江肖洁, 韩士杰 (2014). 长白山 苔原生态系统土壤酶活性及微生物生物量对增温的响 应.土壤学报, 51, 166-175.]

Wang XY (2010). Cultivation and reseeding effects on soil organic matter in the mixed prairie. Soil Science Society of America Journal, 74, 1348-1355.

Wang YH, Gong JR, Liu M, Huang YM, Yan X, Zhang ZY, Xu S, Luo QP (2015). Effects of grassland-use on soil respiration and litter decomposition. Chinese Journal of Plant Ecology, 39, 239-248. [王忆慧, 龚吉芯, 刘敏, 黄永梅, 晏欣, 张梓瑜, 徐沙, 罗亲普 (2015). 草地利用方式对 土壤呼吸和调落物分解的影响. 植物生态学报, 39 , 239-248.]

Willcock S, Phillips OL, Platts PJ, Swetnam RD, Balmford A, Burgess ND, Fanning E (2016). Land cover change and carbon emissions over 100 years in an African biodiversity hotspot. Global Change Biology, 22, 2787-2800.

Wu J, Chen ST Hu ZH, Zhang X (2015). Soil microbial respiration under different soil temperature conditions and its relationship to soil dissolved organic carbon and invertase. Environmental Science, 36，1497-1506. [吴静，陈书涛， 胡正华, 张旭 (2015). 不同温度下的土壤微生物呼吸及 其与水溶性有机碳和转化酶的关系. 环境科学, 36, 1497-1506.]

Xu GH (1986). Soil Microbiological Analysis Method Manual. Agricultural Publishing House, Beijing. [许光辉 (1986). 土壤微生物分析方法手册. 农业出版社, 北京.]

Yang Y, Han GD, Li YH, Chen ZF, Wang CJ (2012). Response of soil respiration to grazing intensity, water contents, and temperature of soil in different grasslands of Inner Mongolia. Acta Prataculturae Sinica, 21(6), 8-14. [杨阳, 韩国 栋，李元恒，陈志芳，王成杰 (2012). 内蒙古不同草原 类型土壤呼吸对放牧强度及水热因子的响应. 草业学 报, 21(6), 8-14.]

Zhang CX, Nan ZB (2010). Research progress on effect of grazing on soil microbes of grassland. Pratacultural Science, 27(1), 65-70. [张成霞, 南志标 (2010). 放牧对草 地土壤微生物影响的研究述评。草业科学, 27(1), 
65-70.]

Zhang PL, Li XG, Li YK, Ying P (2007). Effects of vegetation restoration on soil organic carbon and total nitrogen contents in the alpine agro-pastoral ecotone. Journal of Gansu Agricultural University, 42(2), 98-102. [张平良, 李小刚, 李银科, 尹萍 (2007). 高寒农牧交错带植被恢复对土壤 有机碳、全氮含量的影响. 甘肃农大学报, 42(2), 98-102.]

Zhang WT, Lai HX, Wang YP, Zhang H, Yang T, Lü JL (2008). Microbial populations in different vegetations in sloping field on the Loess Plateau. Acta Ecologica Sinica, 28，4228-4234. [张文婷, 来航线, 王延平, 张海, 杨婷, 吕家珑 (2008). 黄土高原不同植被坡地土壤微生物区 系特征. 生态学报, 28, 4228-4234.]

Zhang YJ, Guo SL, Liu QF, Jiang JS, Wang R, Li NN (2015). Responses of soil respiration to land use conversions in degraded ecosystem of the semi-arid Loess Plateau. Ecological Engineering, 74, 196-205.

Zhang YJ, Yang GW, Liu N, Chang SJ, Wang XY (2013). Review of grassland management practices for carbon sequestration. Acta Prataculturae Sinica, 22, 290-299. [张 英俊, 杨高文, 刘楠, 常书娟, 王晓亚 (2013). 草原碳 汇管理对策. 草业学报, 22, 290-299.]

Zheng W, Jianaerguli, Tang GR, Zhu JZ (2015). Determination and community stability in different legume-grass mixes. Acta Prataculturae Sinica, 24(3), 155-167. [郑伟, 加娜尔 古丽, 唐高溶, 朱进忠 (2015). 不同混播方式下豆禾混 播草地群落稳定性的测度与比较. 草业学报, 24(3), 155-167.] 